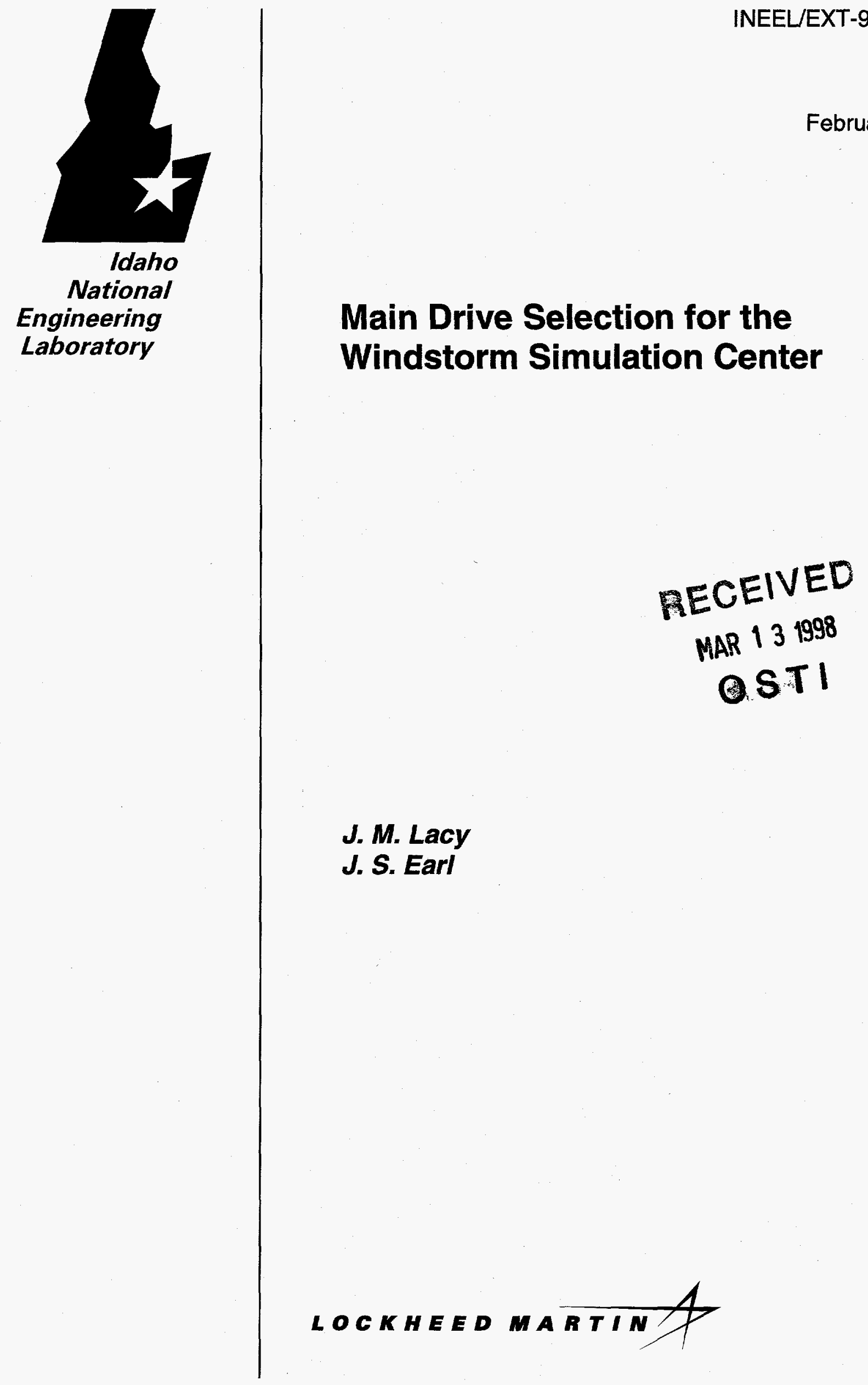




\section{DISCLAIMER}

This report was prepared as an account of work sponsored by an agency of the United States Government. Neither the United States Government nor any agency thereof, nor any of their employees, makes any warranty, express or implied, or assumes any legal liability or responsibility for the accuracy, completeness, or usefuiness of any information, apparatus, product or process disciosed, or represents that its use would not infringe privately owned rights. References herein to any specific commercial product, process, or service by trade name, trademark, manufacturer, or otherwise, does not necessarily constitute or imply its endorsement, recommendation, or favoring by the United States Government or any agency thereof. The views and opinions of authors expressed herein do not necessarily state or refiect those of the United States Government or any agency thereof. 
INEEL/EXT-98-00089

\title{
Main Drive Selection for the Windstorm Simulation Center
}

\author{
J. M. Lacy \\ J. S. Earl
}

Published February 1998

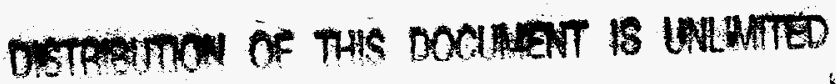

Idaho National Engineering and Environmental Laboratory

The Partnership for Natural Disaster Reduction

Lockheed Martin Idaho Technologies Company

Idaho Falls, Idaho 83415

Prepared for the

U.S. Department of Energy

Idaho Operations Office

Under DOE Idaho Operations Office

Contract DE-AC07-94ID13223 


\section{DISCLAIMER}

Portions of this document may be illegible electronic image products. Images are produced from the best available original document. 


\begin{abstract}
Operated by the Partnership for Natural Disaster Reduction, the Windstorm Simulation Center (WSC) will be a structural test center dedicated to studying the performance of civil structural systems subjected to hurricanes, tornadoes, and other storm winds. Within the WSC, a bank of high-power fans, the main drive, will produce the high velocity wind necessary to reproduce these storms. Several options are available for the main drive, each with advantages and liabilities. This report documents a study to identify and evaluate all candidates available, and to select the most promising system such that the best possible combination of real-world performance attributes is achieved at the best value.
\end{abstract}

Four broad classes of candidate were identified: electric motors, turbofan aircraft engines, turboshaft aircraft engines, and turboshaft industrial engines.

Candidate systems were evaluated on a basis of technical feasibility, availability, power, installed cost, and operating cost. 


\section{EXECUTIVE SUMMARY}

Operated by the Partnership for Natural Disaster Reduction, the Windstorm Simulation Center (WSC) will be a structural test center dedicated to studying the performance of civil structural systems subjected to hurricanes, tornadoes, and other storm winds. Within the WSC, a bank of high-power fans, the main drive, will produce the high velocity wind necessary to reproduce these storms. Several options are available for the main drive, each with advantages and liabilities. This report documents a study to identify and evaluate all candidates available, and to select the most promising system such that the best possible combination of real-world performance attributes is achieved at the best value.

To identify candidates, minimum performance criteria were developed, and a request for information was posted in four different sections of the Commerce Business Daily. The literature was surveyed, and phone calls were placed to a multitude of vendors.

Four broad classes of candidates were identified: electric motors, turbofan aircraft engines, turboshaft aircraft engines, and turboshaft industrial engines.

Candidate systems were evaluated on a basis of technical feasibility, availability, power, installed cost, and operating cost.

The application of turbofan aircraft engines was rejected on the basis of technical feasibility. These engines generate very high temperature airflows, and modifications to reduce the temperature to acceptable levels would be a lengthy and expensive process.

Electric motor systems are feasible, but have several disadvantages, ranking third overall. The entire system, including the power supply, motors, gearboxes, and propellers, would have to be built from scratch. Some re-invention of liquid rheostat controller technology may be necessary for appropriately sized motors, and the WSC may require significantly more structure to house the massive components. The lead time to bring such a system on-line may be three years or more, at an installed cost of $\$ 200 \mathrm{M}$. Supplying energy to the facility would cost another $\$ 2 \mathrm{M} /$ month.

Application of industrial turboshaft (gas turbine) engines is attractive technically, but less so from a cost and schedule perspective, earning a rank of second. A wide variety of these compact, reliable, fuel efficient engines are available, yielding a broad choice of engine sizes and configurations. However, this would be a novel application for this powerplant, and a learning curve should be anticipated. Both propeller and gearbox would be specially designed and fabricated, requiring up to two years. Installed cost is estimated between $\$ 140 \mathrm{M}$ and \$194M.

The result for aircraft turboshaft engines varied significantly from model to model. U.S. made engines appear to be highly optimized for military flight service, and are consequently somewhat expensive. Because the individual 
engines deliver relatively low power, a large number would be required for the main drive, impacting feasibility, installed cost, and operational cost.

The NK-12MV, manufactured in Russia, offers a variety of attractive features. These units have a long service history, both in the air and on the ground, with good reliability statistics (Appendix E). Engines, gearboxes, and propellers are extant, and delivery could occur within months of an order. They produce 11.2 MW each, and run relatively cool, simplifying exhaust management. With modifications, they can burn natural gas if desired. Finally, the installed cost for these units is estimated at $\$ 32 \mathrm{M}$, approximately $\$ 110 \mathrm{M}$ less than the next cheapest alternative. This combination of simplicity of application, low cost, and possibly rapid delivery earned the NK-12MV a ranking of first.

However, more detailed information about the operational characteristics, maintenance, and life cycle cost must be ascertained prior to the final decision to use this unit as the WSC main drive. It is recommended that

1. An in-depth investigation of the NK-12MV will be initiated, including ground-based operating characteristics, detailed life cycle costs, and availability.

2. WSC analysis, design, and project management studies assume a main drive system composed of NK-12MV units until the detailed analysis substantiates the unit's suitability for this application.

3. If the NK-12MV is determined to be unsuitable, then the industrial turboshaft engine should be investigated as the next logical choice.

4. Finally, the possibility of a hybrid system should be explored. In this case, a core of $2-4$ electric motor driven fans might be placed in the center of the array, providing airflow for checkout and low-speed tests. This arrangement would avoid the large infrastructure costs of a purely electric system, while allowing a simple and rapid means of performing low velocity tests, calibration, and instrument check-out. 


\section{ACKNOWLEDGMENTS}

The authors would like to thank the many individuals who assisted us in identifying and investigating options for the Windstorm Simulation Center main drive. Their expertise and experience were invaluable to this effort. The names of these contributors are given in Appendix C.

We would also like to thank our technical review team for their perspective and insight, to which this document owes much. Reviewers were

Mr. J. A. Alberico, Procurement Agent, Lockheed Martin Idaho Technologies Co. (LMITCO), Idaho Falls, ID

Mr. J. A. Dearien, Mechanical Engineering, LMITCO, Idaho Falls, ID

Mr. W. Johnson, Sverdrup Technology Inc./ Technology Group, Tullahoma, TN

Mr. T. K. Larson, Fluid Mechanics, LMITCO, Idaho Falls, ID

Dr. D. G. Moore, Chief Engineer, LMITCO, Idaho Falls, ID

Mr. G. L. Parlier, Systems Engineering, LMITCO, Idaho Falls, ID

Mr. M. L. Perry, Lead Projects Engineer, Lockheed Martin Low Speed Wind Tunnel, Smyrna, GA

Mr. W. D. Richins, Applied Mechanics, LMITCO, Idaho Falls, ID

Mr. G. D. Seifert, Ascension Island Wind Energy Project Manager, LMITCO, Idaho Falls, ID 


\section{CONTENTS}

ABSTRACT

EXECUTIVE SUMMARY

1. INTRODUCTION

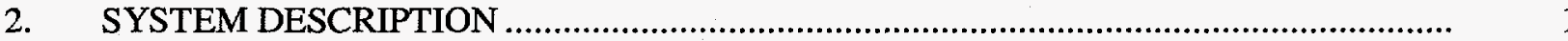

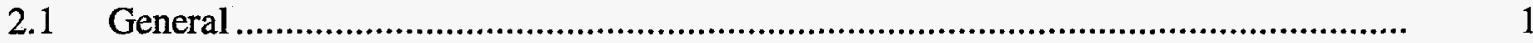

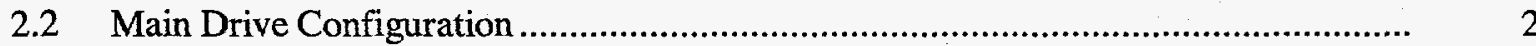

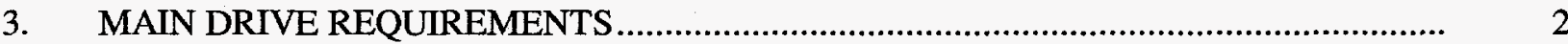

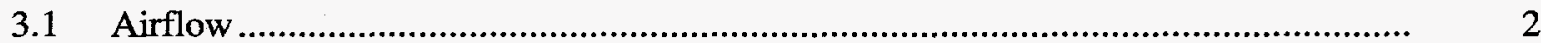

3.1.1 Test Section Airflow Speed .......................................................................

3.1.2 Test Duration.......................................................................................

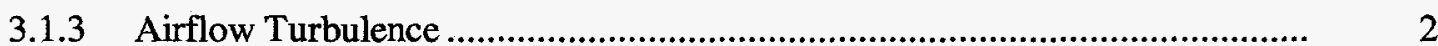

3.1.4 Airflow Temperature ..................................................................... 3

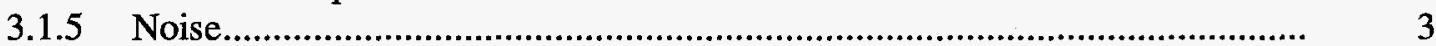

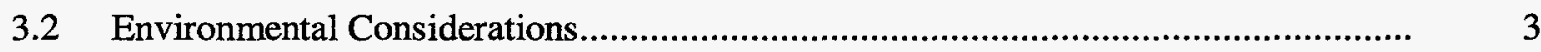

3.2.1 Combustion Products and Airborne Pollutants .............................................

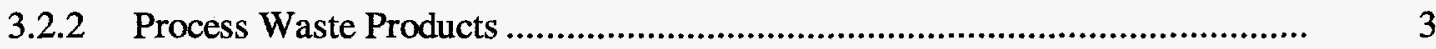

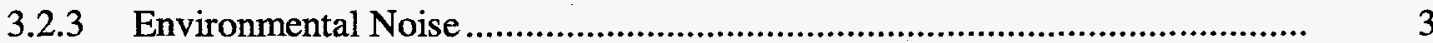

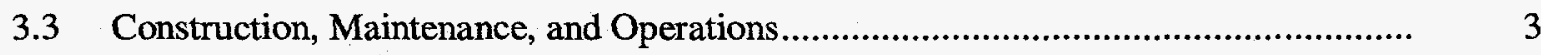

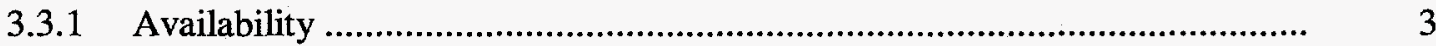

3.3.2 System Control Issues...........................................................................

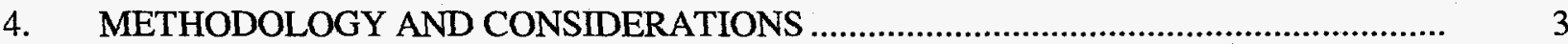

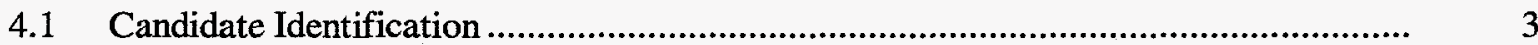

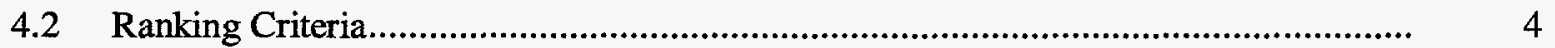

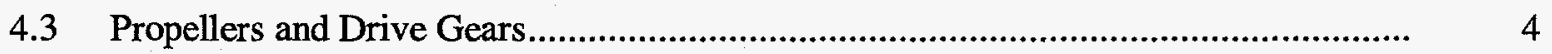

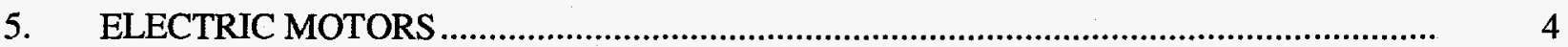

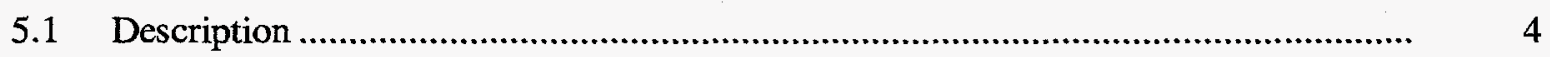

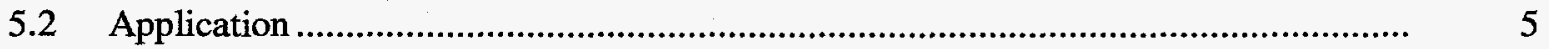




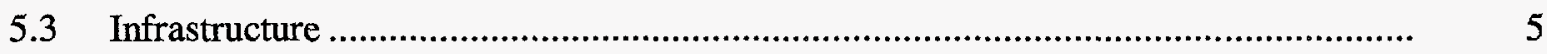

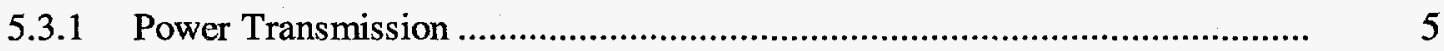

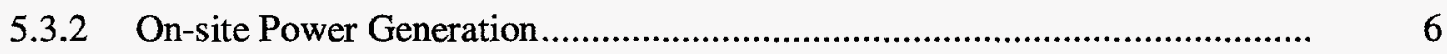

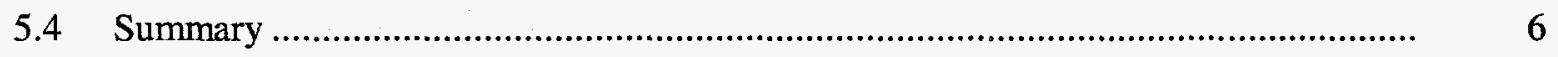

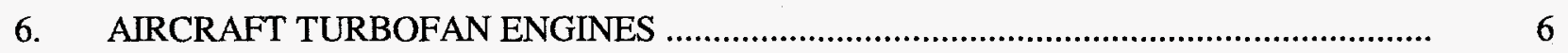

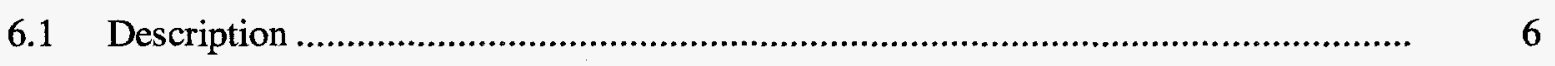

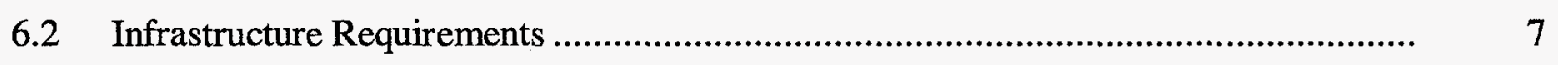

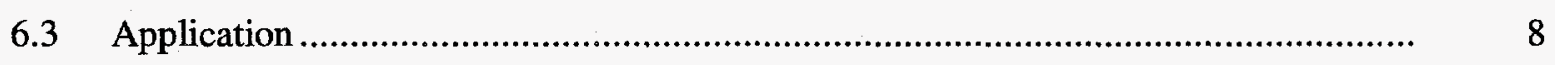

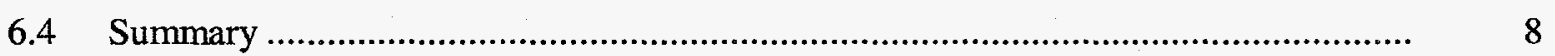

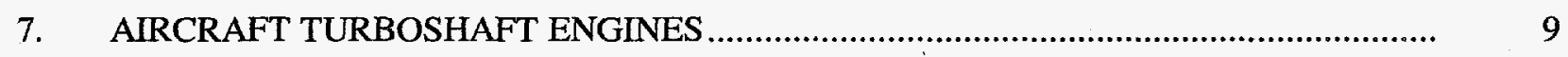

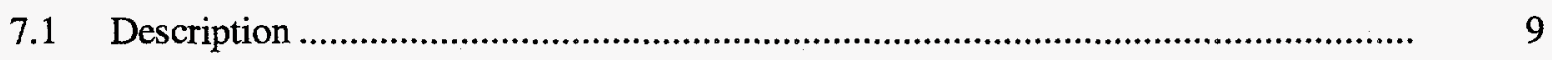

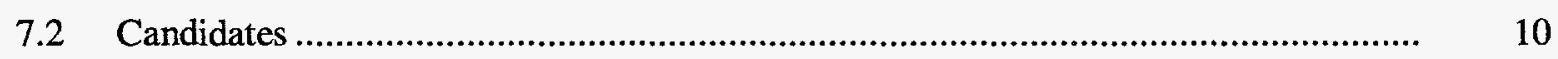

7.2.1 U.S.-Made Turboprops .................................................................... $\quad 10$

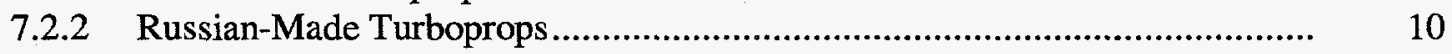

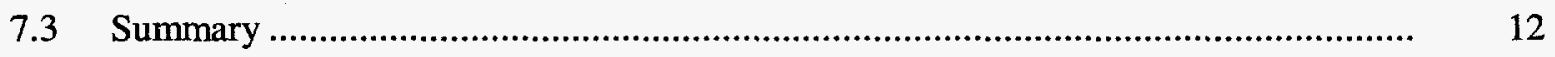

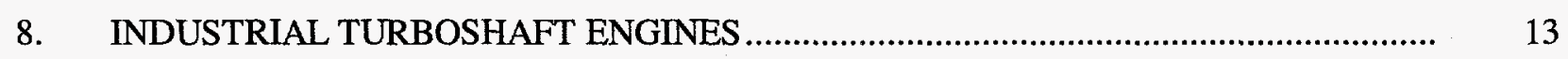

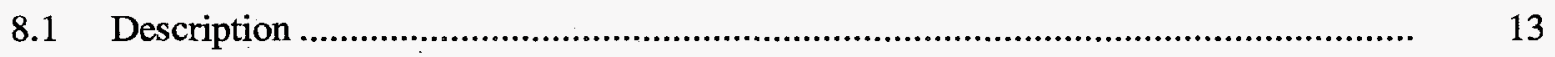

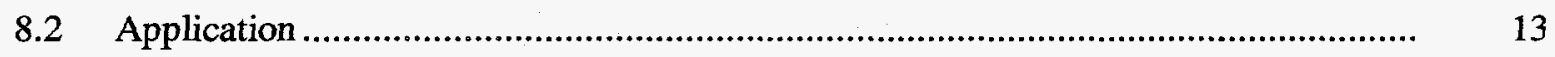

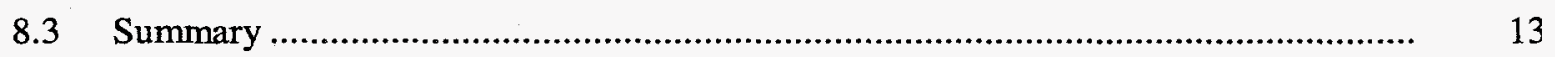

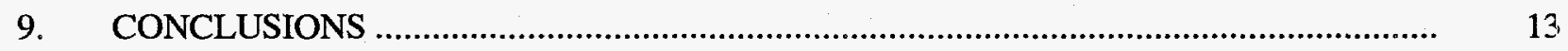

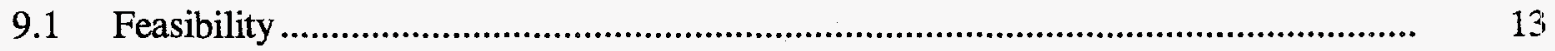

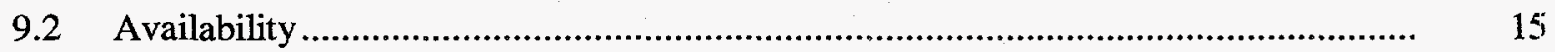

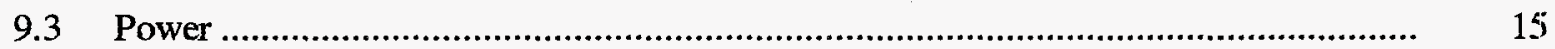

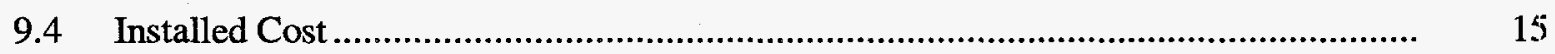

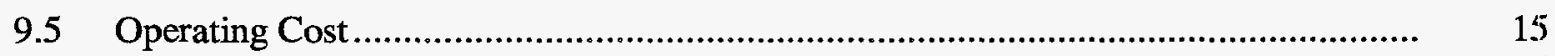

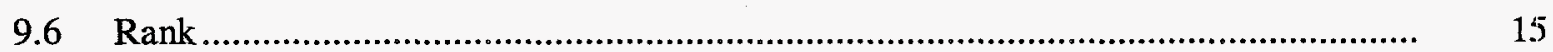


9.7 Recommendations

10. REFERENCES

Appendix A-Conceptual Windstorm Simulation Center Main Drive Power Calculations

Appendix B-Request for Information Commerce Business Daily

Appendix C-List of Contacts

Appendix D-Characteristics of Candidate Systems

Appendix E-Kuznetsov NK12-MV Properties

FIGURES

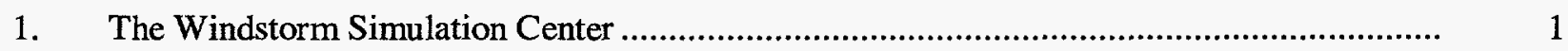

2. Electric Fan Array at NASA Ames $40 \mathrm{ft} \times 80 \mathrm{ft}$ wind tunnel.................................. 5

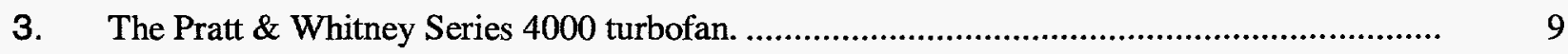

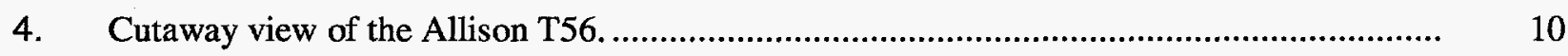

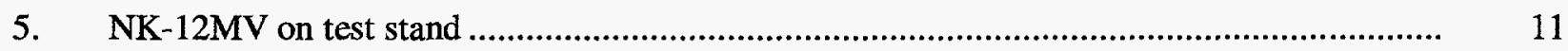

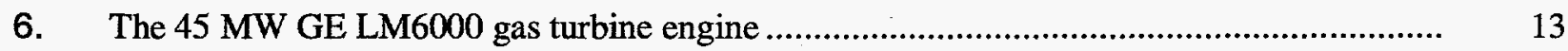

TABLES

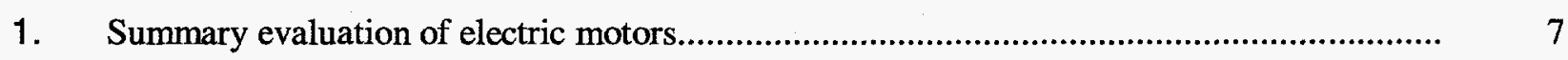

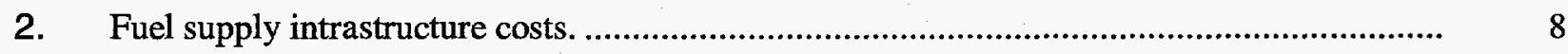

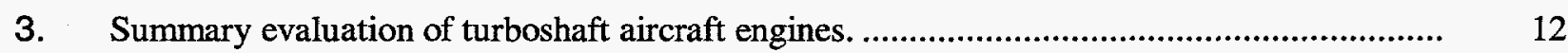

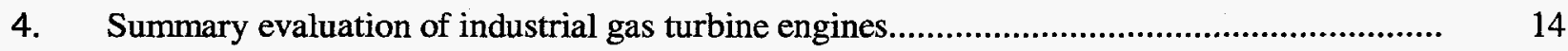




\section{Main Drive Selection for the Windstorm Simulation Center}

\section{INTRODUCTION}

The Windstorm Simulation Center (WSC) will be a structural test facility dedicated to studying the performance of civil structural systems subjected to hurricanes, tornadoes, and other storm winds. A bank of high-power fans, the main drive, will produce airflow at velocities up to $90 \mathrm{~m} / \mathrm{s}(200 \mathrm{mph})$ at the test section.

Because of the large power consumption expected of the main drive, costs associated with its installation and operation will be a significant portion of the overall facility costs. Therefore, a careful evaluation of all possible candidate systems is appropriate to ensure that the best possible combination of attributes is achieved in the final installed system.

This document reports the methodology and findings of a study to identify, evaluate, and rank candidate main drive systems. Candidates were evaluated by the technical feasibility, availability for installation, power, and order-ofmagnitude installation and operating cost to achieve the published performance specifications for the WSC. Where appropriate, other data is included in the discussion and analysis. Because of the conceptual nature of the WSC design, life cycle cost data could not be applied as a measure of comparison.

\section{SYSTEM DESCRIPTION}

\subsection{General}

The conceptual design of the WSC, ${ }^{1}$ developed by the Idaho National Engineering and Environmental Laboratory (INEEL), uses a straight-through, open circuit, open test section layout, as shown in Figure 1. Directly downstream of the bell-mouth inlet, a bank of fans produces the required airflow. Placement of the fans upstream of the test section protects them from debris that may be generated, by either injection into the airflow or failure of the test specimen. Fans will be individually ducted and faired to optimize efficiency. Airflow produced by the fan array flows through a contraction, to a

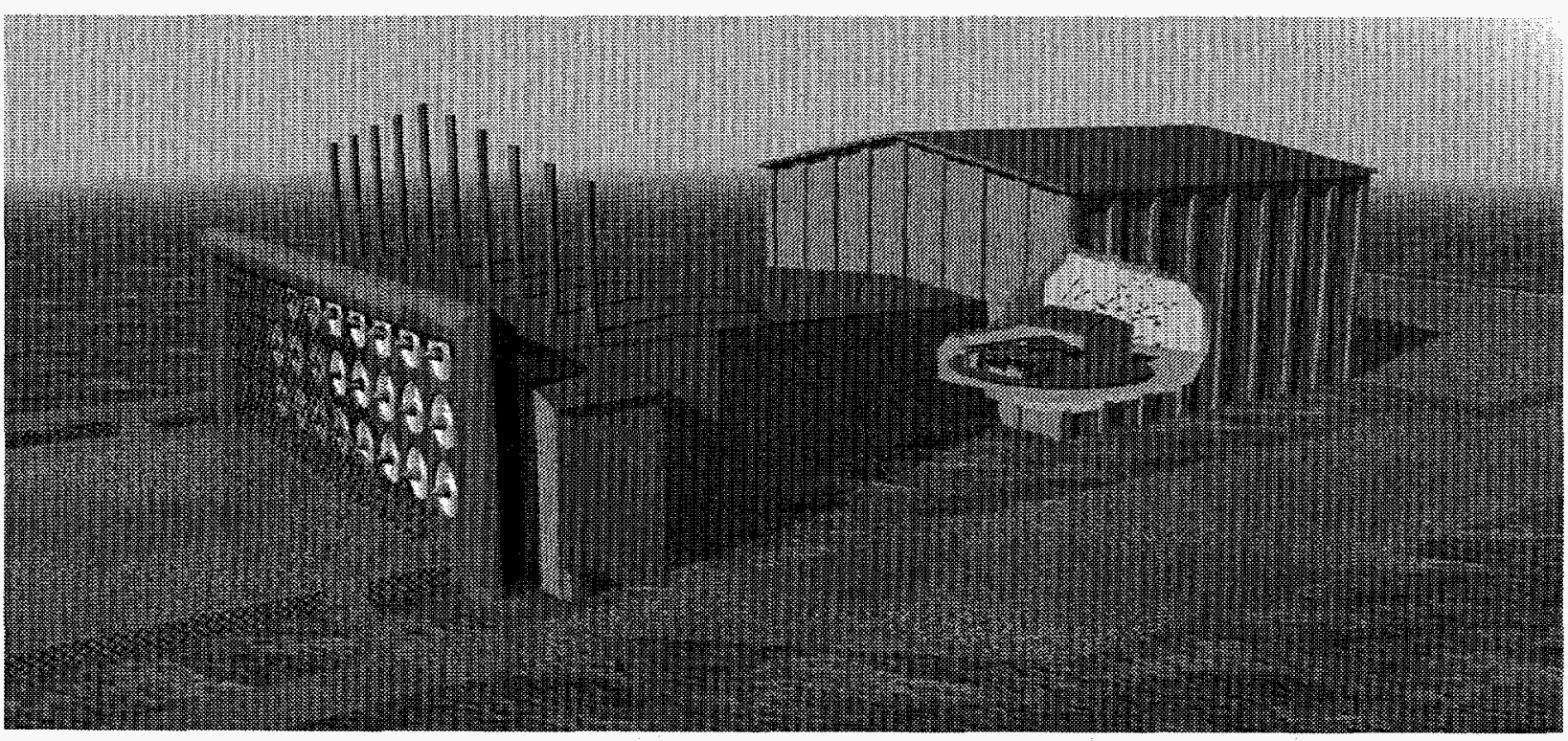

Figure 1. The Windstorm Simulation Center. 
throat measuring approximately $24 \mathrm{~m}(80 \mathrm{ft})$ wide by $12 \mathrm{~m}$ high ( $40 \mathrm{ft}$ ), producing a highvelocity jet.

The jet then passes through an open test section area, where a test specimen rests on a $24 \mathrm{~m}(80 \mathrm{ft})$ diameter turntable, and then proceeds outdoors without further treatment.

Storm wind turbulence is produced in an active, mechanical manner. Longitudinal gusting is produced by individually controlling and cycling the thrust of the fans in the array. This turbulence is then intensified, and the lateral component added, by an active vertical airfoil cascade mounted at the throat of the contraction.

Because test time in the WSC will be quite valuable, a construction facility will be provided nearby. There, test articles will be constructed and instrumented before being transported into the WSC. Once a test article is mounted on the turntable, sensors can be connected to the data collection system, and checked out prior to testing. This approach ensures efficient, cost effective use of the facility, and offers high potential throughput.

\subsection{Main Drive Configuration}

The main drive array may be either of two basic configurations: direct drive, or remote drive. In the "direct drive" configuration, each fan is directly mounted to the output shaft of an engine, which is mounted in the array shown in Figure 1. In the "remote drive" configuration each fan is attached to a gearbox mounted in the array. The gearbox is driven by a shaft from a motor or engine mounted in a room below the fan array.

Direct drive systems have the advantage of simplicity of design, fabrication, and installation, and require less structure to house. Thus the initial cost would be lower. Engine overhauls or significant maintenance may require that fans be removed from the array by crane.

Remote drive systems require more structure and machinery, but offer a wider array of options for type and size of motor, and may offer the option of driving multiple fans from each motor.

\section{MAIN DRIVE REQUIREMENTS}

The Partnership for Natural Disaster Reduction has developed a set of functional requirements for the $\mathrm{WSC}^{2,3,4}$ for full-scale structural wind testing. In summary, the WSC is required to reproduce Category 5 hurricane wind and rain on full-scale two-story residential structures, and other structures or components of similar size, in a controllable, repeatable manner. This, in turn, generates requirements specific to the main drive. These requirements are listed and discussed in the following paragraphs.

\subsection{Airflow}

\subsubsection{Test Section Airflow Speed}

The WSC shall be capable of generating a sustained wind speed of $70 \mathrm{~m} / \mathrm{s}(160 \mathrm{mph})$, with a maximum of $90 \mathrm{~m} / \mathrm{s}(200 \mathrm{mph})$ averaged across the $300 \mathrm{~m}^{2}\left(3,200 \mathrm{ft}^{2}\right)$ test cross section, producing a maximum volumetric flow rate of $27,000 \mathrm{~m}^{3} / \mathrm{sec}(57.2 \mathrm{million} \mathrm{cfm})$. Airflow is expected to pass through a contraction from the fan section to the throat to achieve this speed. The contraction ratio is currently not specified, although a ratio near unity is preferred to maintain the lateral turbulence content of the flow. Initial calculations (Appendix A) indicate that the power required to achieve this airflow will fall between $250 \mathrm{MW}$ and $300 \mathrm{MW}$, depending on the outcome of ongoing design optimization studies.

\subsubsection{Test Duration}

To simulate the passage of a storm, the WSC shall be able to produce hurricane intensity wind for up to 6 hours, and lower intensity wind for up to 12 hours, without interruption.

\subsubsection{Airflow Turbulence}

The WSC shall be capable of reproducing turbulence representative of surface winds. This requirement is to be applied only across those 
ranges of frequency and mean velocity pertinent to structural response. (35-90 $/ \mathrm{m} / 80-200 \mathrm{mph}$, $0.1-20 \mathrm{~Hz}$ ). The main drive system is expected to contribute to the longitudinal wind speed variation by varying the thrust of each fan in a controlled fashion.

\subsubsection{Airflow Temperature}

The temperature of the airflow at the test cross section shall be substantially uniform, and remain less than $40^{\circ} \mathrm{C}$. A water spray system, designed for rain injection, will be available to cool abnormally high temperature airflows for brief periods.

\subsubsection{Noise}

Noise at the test section shall be limited such that functionality of instruments on or near the test article is not impacted, and the behavior of the test article is not affected. It is anticipated that noise reduction technology will be employed in the contraction and test section; however, detailed information on the acoustic energy produced by candidate main drive systems will be required for design and evaluation of these systems.

\subsection{Environmental Considerations}

\subsubsection{Combustion Products and Airborne Pollutants}

Production of combustion products and airborne pollutants shall be limited to levels deemed acceptable by the INEEL and the state of Idaho, without resort to special waiver.

\subsubsection{Process Waste Products}

Waste streams produced by candidate main drive systems shall be identified so that suitable treatment and associated costs may be determined. Examples of waste products might be coolants, lubricants, cleaning agents, or other substances used during the normal operation and maintenance of the main drive system.

\subsubsection{Environmental Noise}

Excessive noise outside the WSC building may adversely affect local fauna, occupants of neighboring facilities, or travelers on the adjacent Highway 20. Therefore, sufficient information on noise generated by candidate systems is required to characterize the noise in the surrounding area.

\subsection{Construction, Mainten- ance, and Operations}

\subsubsection{Availability}

The current construction schedule requires delivery of the main drive system to start in mid-2000 and end in early 2001 . Requisition is not expected to occur until 1999, leaving a maximum of two years to prepare and deliver the main drive. This short schedule is driven by the needs of the facility's potential customers.

\subsubsection{System Control Issues}

Preliminary model studies indicate that a minimum of six fans may be required to create the velocity profiles and turbulence content required of the WSC. As the array increases, finer control will be available to manipulate the airflow. However, costs associated with system construction, maintenance, operation, and reliability can be expected to increase significantly with the number of fans. In lieu of a parametric study to determine the optimum number of fans, this report will simply recognize that system feasibility will become problematic for candidates requiring a very large array.

\section{METHODOLOGY AND CONSIDERATIONS}

\subsection{Candidate Identification}

In early March of 1997, an extensive search was initiated to identify and characterize main drive candidates. An announcement was published in four different sections of the Commerce Business Daily (Appendix B) in June requesting information from vendors. Reference 
texts, such as Jane's Aero Engines, ${ }^{5}$ proved invaluable to develop much of the information on aircraft based turbomachinery. However, most information was gathered by phone conversations with system vendors and engineers. These contacts are listed in the References and in Appendix C.

\subsection{Ranking Criteria}

Systems that could reasonably be expected to meet the requirements listed above were evaluated by the following criteria.

- Technical Feasibility: High marks were given to candidates that currently exist and require no, or only slight, modifications for this application; followed by candidates designed and fabricated by vendors with significant experience in wind tunnel drive applications. Low marks were given to candidates that would require extensive modification with low confidence in the resulting performance.

- Availability: This category represents the lead time to procure and install the candidates. It is assumed that main drives must begin to arrive on-site in mid-2000.

- Installed Cost: This includes the purchase price of the main drives, and energy supply systems to support them.

- Operating Cost: Operating Cost was calculated assuming the main drive will operate for 30 hours per month at an average of $70 \%$ full power.

Other life cycle cost data, such as reliability, maintainability, and emissions are reported where available. But, because this information is not consistently available for all systems, it was not included as a factor in the analysis.

\subsection{Propellers and Drive Gears}

As critical components of the main drive system, the cost of propellers and reduction gearing from the engine/motor to the propeller must be considered. With the exception of aircraft turbofans, all power sources discussed in the following sections will require a gear and propeller system. For special design systems, the cost to design and fabricate new propellers and gears must be included in the installed cost. Production gears and propellers are available for aircraft-derived systems at significantly less cost and quicker delivery, although they may not be optimized for ground test applications.

Propellers would be fabricated from aluminum in smaller sizes (less than $17 \mathrm{ft}$ ) or composites in larger sizes, and are expected to cost between \$3M and \$4M per set. Variable pitch control does not affect this cost significantly. Propellers in the size range contemplated typically require 1 to 2 years to deliver the first set, with subsequent sets following more rapidly. ${ }^{6}$

Reduction gears are necessary to transmit engine power, typically at $3,000-5,000 \mathrm{rpm}$, to the propeller at a much lower speed. Stress considerations limit propeller speed to approximately $700 \mathrm{rpm}$. Single-stage reduction gears transmitting $100,000 \mathrm{ft}$-lb of torque $(11.2 \mathrm{MW}$ @ $700 \mathrm{rpm}$ ) have been estimated to cost $\$ 130,000$ per set, and require $38-40$ weeks to deliver.?

\section{ELECTRIC MOTORS}

\subsection{Description}

Electric motors are traditionally the first choice main drive for wind tunnel applications. ${ }^{8}$ Electric motor driven wind tunnels range in size from table-top models to the $40 \mathrm{ft} \times 80 \mathrm{ft} / 80 \mathrm{ft} \times$ $120 \mathrm{ft}$ facility at Moffett Field operated by NASA Ames Research Center (Figure 2). Electric systems offer control and reliability at the cost of large supporting infrastructure and system size. 


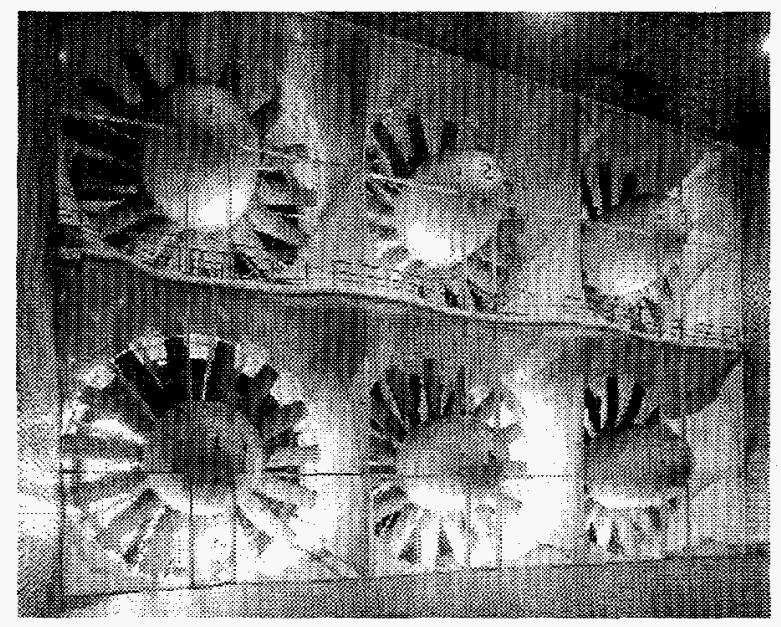

Figure 2. Electric Fan Array at NASA Ames $40 \mathrm{ft} \times 80 \mathrm{ft}$ wind tunnel. ${ }^{\mathrm{a}}$

\subsection{Application}

An electric motor-driven system would be specially designed and fabricated for the WSC. Therefore the properties of the system cannot be comparatively discussed in this document. However, very large electric motors are currently used in wind tunnels and other applications around the world, and the general properties of these systems are well known.

While form factors are not fixed, electric motors are typically dimensionally large and massive in comparison with combustion engines of similar output. A typical 10,000 hp (7.5 MW) coupled synchronous motor weighs between 45,000 and $70,0001 b^{9}$

General Electric ${ }^{10}$ has provided AC motors for wind tunnel applications at sizes up to $19 \mathrm{MW}$. These motors typically cost approximately $\$ 250 / \mathrm{kW}$. These large systems have in the past employed liquid rheostat technology for the controller, which has since been abandoned in favor of the Load Commutated Inverter (LCI) controller. While LCI motors are more economical, they do not permit the power levels achiev-

a. J. Allmen, "Aeroacoustic Wind Tunnel Modification Underway," National Aeronautics and Space Administration, http://ccf.arc.nasa.gov/wind tunnel/article.html July 8, 1997. able with liquid rheostat motors. Because the technology for liquid rheostat control is in essence lost, new drive motors could be limited to $10,000 \mathrm{hp}(7.5 \mathrm{MW})$ each, without some technology development effort. It is estimated that these motors would cost $\$ 2 \mathrm{M}$ each.

Because of the large size and extreme weight of the electric motors, they would be placed below grade. A remote drive configuration (drive shaft to gear box to propeller) would be used in this instance.

\subsection{Infrastructure}

The energy required by electric motors may be supplied by transmitting power from a remote site, or by generating and conditioning the power locally (cogeneration).

\subsubsection{Power Transmission}

The Idaho Power Company Planning Department investigated the possibility of supplying power to the WSC at levels between $120 \mathrm{MW}$ and $300 \mathrm{MW} \cdot .^{11,12}$ While the analysis of the power supply infrastructure assumes a peak demand of $300 \mathrm{MW}$, very large motors can draw up to 7 times their rated current when first started (locked rotor current). Without proper consideration, this effect could cause severe voltage sag in both the local and surrounding regions. Detailed analysis is required to confirm the peak demand, which may be greater than $300 \mathrm{MW}$.

Existing lines into the INEEL could not support this load, so a new transmission line would be required from the Brady Substation at American Falls to the Antelope Station at INEEL, a distance of 56 miles, and new line from there to the WSC site. These lines would be either $230 \mathrm{kV}$ or $345 \mathrm{kV}$, depending on the outcome of detailed analysis. Upgrades would be required to both the Brady and Antelope substations, along with a new substation at the WSC site. Idaho Power estimates the total installation cost at $\$ 30 \mathrm{M}$ for $230 \mathrm{kV}$ line, and $\$ 40 \mathrm{M}$ if a $345 \mathrm{kV}$ line is necessary. 
Sufficient cheap hydroelectric power is anticipated to be unavailable to supply the anticipated demand, making more expensive coal-generated power necessary. This is reflected in the estimated electric power cost of $\$ 0.05 / \mathrm{kWhr}$. The facility would also be charged a demand fee on the peak power demand of $\$ 5.00 / \mathrm{kW}$ per month. Idaho Power estimated that the monthly cost could range as high as $\$ 3.6 \mathrm{M} /$ month.

Idaho Power was not certain that $300 \mathrm{MW}$ of power is available in the region to supply the facility. With very little margin available, future demand growth in the region could have a serious negative impact on the operation of the WSC.

Approximately 3 years would be required to place the transmission system: up to 2 years to site, permit, and acquire the route, and one year to construct the facilities.

\subsubsection{On-site Power Generation}

Rather than bringing electric power in from the outside, a power generation facility could be sited near the WSC. One option is to use 2 or 3 large gas turbine engines to generate the required power.

A survey of available gas turbine engines, developed by Turbine Systems Engineering, Inc. ${ }^{13}$ is shown in Appendix C. This survey shows that the purchase cost of gas turbines with output between 40 and $60 \mathrm{MW}$ average around $\$ 300 / \mathrm{kW}$. Conversations with General Electric, Salt Lake City ${ }^{14}$ confirm this estimate. GE estimates that the gas-turbines alone (such as the $7 F A$ ) would cost $\$ 96 \mathrm{M}$. Idaho Power estimates the cost of the associated substation at $\$ 10 \mathrm{M}-$ $\$ 15 \mathrm{M}$, placing the installed cost to $\$ 106$ $\$ 111 \mathrm{M}$.

A previous project at the INEEL ${ }^{15}$ sought to design and build a rail-car mounted mobile generating station. In cooperation with Stewart and Stevenson, a system was developed to deliver 40-50MW of electricity. Each rail-car unit would have cost $\$ 15 \mathrm{M}$. This confirms the above estimate of $\$ 300 / \mathrm{kW}$. Operating cost, including amortization over 15 years, was between 7 and 12 cents $/ \mathrm{kWh}$, with fuel accounting for approximately $4 \phi$ of that. At the time the project was halted, no customers had been identified on the INEEL site for the power, although the market appeared to be strong on a nationwide scale.

No upcoming projects at the INEEL have been identified which would share the costs to bring this amount of power to the site.

\subsection{Summary}

Because an electric motor driven system would be a special design-build project, the performance characteristics could be tailored to meet the WSC requirements exactly. Disadvantages are the large system size, which would require larger facilities and subsequent costs, and long lead time to procure. The installed cost for an electric motor system is expected to fall between \$173M and \$240M, with operating costs between $\$ 20 \mathrm{M}$ and $\$ 25 \mathrm{M}$ per year (Table 1).

\section{AIRCRAFT TURBOFAN ENGINES}

\subsection{Description}

A variety of modern high-bypass turbofan aircraft engines are available in the power ranges of interest. These engines, developed for large commercial transport aircraft, boast high power, energy efficiency, and reliability in a compact, lightweight package. They typically have a diameter less than $3 \mathrm{~m}$ and weigh less than 4 tonnes, producing 25 to $60 \mathrm{MW}$ of power.

The modern turbofan engine is essentially a turbojet with an oversized stage 1 compressor. This fan compresses air flowing into the engine (core flow), and also pushes air around the outside of the engine (bypass flow). By using turbine power to drive a large mass of bypass air, the overall exit velocity is reduced, increasing propulsive efficiency and decreasing noise. Typically, the ratio of bypass flow to core flow (the bypass ratio) ranges between 5 and 8 in newer turbofans. 
Table 1. Summary evaluation of electric motors.

Summary Analysis

Feasibility on scale of $0-4$

Installation practical

Vendors exist

Technology available

Resources available
Electric Motors

2.75

$4 \quad$ Units are commonly used in smaller wind tunnel applications

4 GE, Westinghouse are only identified vendors capable of the size required

2 Some re-invention of starter technology may be necessary

1 Power may not be available. May require on-site generation.

3 years Power infrastructure critical

Availability / Installation Schedule

\begin{tabular}{|c|c|c|c|c|c|}
\hline \multicolumn{2}{|c|}{ Unit Cost Range } & \multirow{2}{*}{$\begin{array}{l}\text { Unit } \\
\mathrm{kW}\end{array}$} & \multirow{2}{*}{$\begin{array}{l}\text { System } \\
\text { Quantity } \\
300,000\end{array}$} & \multicolumn{2}{|c|}{$\begin{array}{c}\text { System Cost Range } \\
(\$ \mathrm{M})\end{array}$} \\
\hline$\$ 250$ & $\$ 350$ & & & $\$ 75$ & $\$ 105$ \\
\hline$\$ 10$ & $\$ 15$ & $\mathrm{~kW}$ & 300,000 & $\$ 3$ & $\$ 5$ \\
\hline$\$ 3,000,000$ & $\$ 4,000,000$ & each & 20 & $\$ 60$ & $\$ 80$ \\
\hline$\$ 5,000,000$ & $\$ 10,000,000$ & each & 1 & $\$ 5$ & $\$ 10$ \\
\hline$\$ 30,000,000$ & $\$ 40,000,000$ & power & 1 & $\$ 30$ & $\$ 40$ \\
\hline
\end{tabular}

Operating Cost (per month)

\begin{tabular}{lccrrl} 
Maintenance & $\$ 10,000$ & $\$ 50,000$ month & 1 & $\$ 0.010$ & $\$ 0.050$ No Data \\
Fuel /Energy & $\$ 0.035$ & $\$ 0.050 \mathrm{kWHr}$ & $6.30 \mathrm{E}+06$ & $\$ 0.221$ & $\$ 0.315$ \\
Demand Fee & $\$ 5$ & $\$ 5 \mathrm{~kW}$ & 300,000 & $\$ 1.500$ & $\$ 1.500$ \\
\hline Monthly Cost $\mathbf{( \$ M )}$ & & & & $\$ 1.73$ & $\$ 1.87$
\end{tabular}

Assumptions:

20 - 15MW motors driving array of 20 fans @ 2.9 million cfm each

Run time 30 hours/month at an average of $70 \%$ full power: $6,300,000 \mathrm{kWhr} / \mathrm{month}$

To increase fuel efficiency, modern designs use very high combustion chamber temperatures, which in turn lead to high exhaust temperatures. Estimates for the averaged exit air temperature, including bypass air, range from $800 \mathrm{~K}$ to $1000 \mathrm{~K}\left(525-725^{\circ} \mathrm{C}\right)$.

\subsection{Infrastructure Requirements}

Turbomachinery requires an infrastructure to supply energy much as electric systems do. This infrastructure includes the tankage, supply lines, pumps, temperature control, and truck depot facilities necessary to transport, store, condition, and deliver fuel to the engines. These systems are common to all liquid fueled turbomachinery discussed in this and following sections.

Reference 1 considered the cost to construct the fuel storage, delivery and truck depot facilities necessary to support a liquid fueled main drive system. It was calculated that a capacity for 200,000 gal of fuel was required initially, with a capability to expand to $400,000 \mathrm{gal}$ if desired in the future.

The conceptual facility design included

- Two 100,000 gal tanks

- Concrete foundations and curbs to prevent spills 
- Tank heaters and insulation to maintain fuel temperature

- A continuous recirculation pump system to provide $600 \mathrm{gpm}$ fuel flow with $25 \%$ return flow at maximum engine consumption

- Heated 4 in. fuel lines

- Fuel control valving

- Tank truck depot.

The associated cost, detailed in Table 2 , summed to $\$ 2.2 \mathrm{M}$, including overhead and procurement fees. Addition of tankage, lines, and pumps for a 400,000 gal capacity would add $\$ 1.8 \mathrm{M}$ for a total of $\$ 4 \mathrm{M}$. Fuel costs for turbomachinery have been estimated by other INEEL projects ${ }^{15}$ at approximately $\$ 0.04 / \mathrm{kWhr}$, which compares favorably with electric power.

Table 2. Fuel supply infrastructure costs.

Infrastructure Construction: 200,000 gal Fuel Storage with Environmental Protection

\begin{tabular}{lr} 
Sitework-excavation/backfill & $\$ 21,225$ \\
Concrete-pads/foundation & 65,000 \\
Metals-pipe stand and guard post & 26,000 \\
Thermal and moisture protection- & 125,440 \\
insulation & \\
Finishes-painting, etc. & 80,000 \\
Special construction-pump house & 6,500 \\
Mechanical-tank, piping, pumps, etc. & $1,821,397$ \\
Electrical-control system & 60,000 \\
Total, 200,000 gallon capacity & $\$ 2,205,562$ \\
Additional 200,000 gallons & $1,821,397$ \\
Total, 400,000 gallon capacity & $\$ 4,026,959$ \\
\hline
\end{tabular}

It is also possible to fuel internal combustion systems with natural gas. Upon request, Intermountain Gas Company ${ }^{16}$ developed an estimate of the cost to deliver natural gas to the INEEL site. A line would be laid from the Northwest pipeline at the Aberdeen Tap, near the city of American Falls, 69 miles to the
INEEL Central Facilities Area (CFA), and thence to the Disaster Prevention Center site.

It was assumed for this estimate that the WSC peak demand would be 15,000 therms/ hour ( 1 therm $=100,000 \mathrm{BTU})$, and that the gas must be delivered at 300 psi to the INEEL site. This could be accomplished with a 12-in. line, at an approximate cost of $\$ 20 \mathrm{M}$. If detailed analysis shows that a 16-in. line is required, the cost would rise to $\$ 30 \mathrm{M}$. The accuracy of the estimate is plus or minus $15 \%$.

If a gas line were supplied, the cost of natural gas is expected, at the worst case, to range near $\$ 0.25 /$ therm, or $\$ 0.0085 / \mathrm{kWhr}$.

\subsection{Application}

Table D-1 in Appendix D lists some of the significant engine families, along with power and cost ranges. Engineers from Boeing, ${ }^{17}$ General Electric, ${ }^{18}$ and Pratt \& Whitney ${ }^{19}$ (Figure 3) were contacted to discuss the applicability of these engines to wind tunnel operations.

These engines have been extensively optimized for aircraft use, and modifications required for this application would be extensive. Among several difficulties and re-design issues raised by the specialists was the assertion that it is not possible to duct the hot core exhaust away from the bypass flow without damaging the engine. Thus it is not possible to decrease the airflow temperature from the $800-1,000 \mathrm{~K}$ range to within the required range of less than $310 \mathrm{~K}$.

\subsection{Summary}

Aircraft turbofans have been optimized over the years to produce very high thrust from a small, lightweight, and reliable package. Much of this progress has been made by developing new materials, coatings, and cooling schemes to survive increasingly hot exhaust gas temperatures. Although exhaust gas is mixed with a larger volume of bypass air, the average airflow temperature is still much hotter than acceptable in the WSC. Because all the airflow that passes 


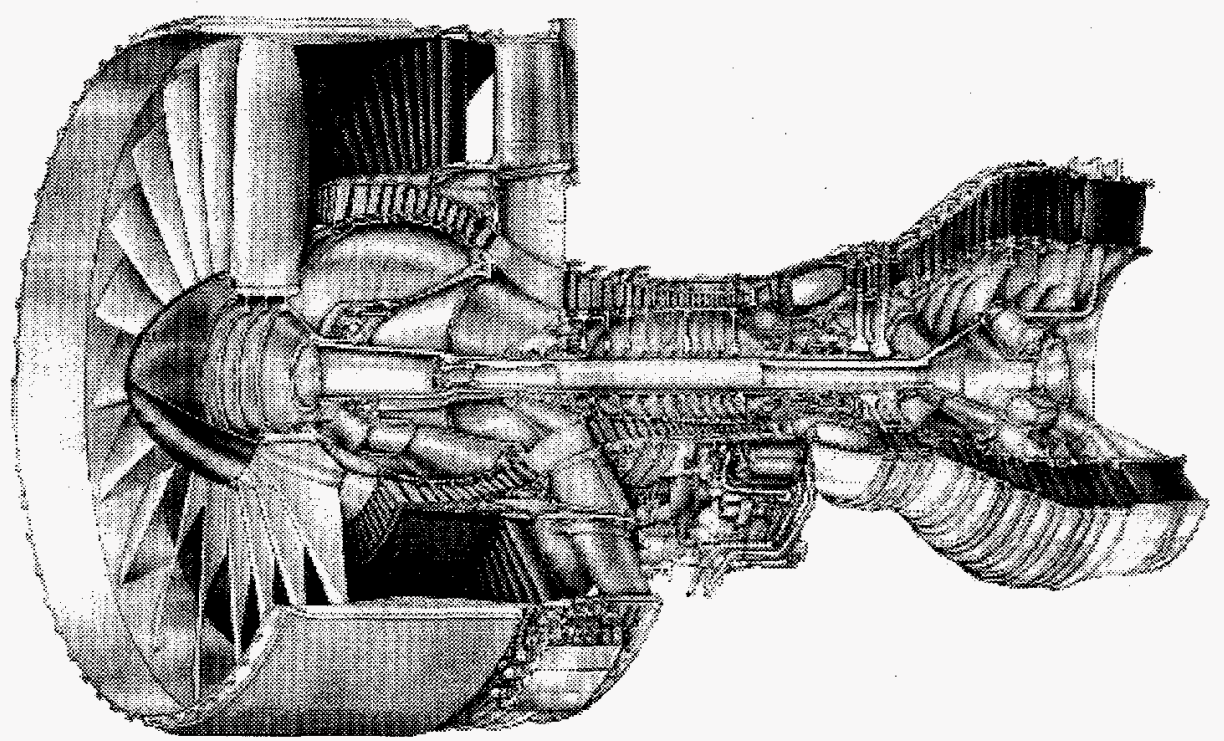

Figure 3. The Pratt \& Whitney Series 4000 turbofan.

through the facility must pass through the main drive first, there is no opportunity to cool it by any other mixing. In addition, the intended strategy of cycling the main drive power continuously cannot be employed without cycling the engine rotational speed, which degrades the life of the engines. For these reasons turbofans do not meet the requirements of the WSC, and will not be considered further.

\section{AIRCRAFT TURBOSHAFT ENGINES}

\subsection{Description}

Aircraft turboshaft (commonly called turboprop) engines are another modification of the turbojet. In this case, turbine power is used to drive a shaft, to which a propeller set is attached. Residual thrust from the turbine exhaust typically accounts for approximately $5 \%$ of the total thrust, with the remainder attributable to the propeller. Bypass ratios for turboprop engines range around a value of 20 . Thus, for a given power output and air mass flow rate, the outlet air velocity is lower, reducing noise and increasing efficiency, with respect to turbofans. In aircraft applications, these improvements come at the cost of lower aircraft speed, which accounts for their lack of popularity in western countries today.

A relatively new development in turboprop design is the propfan. In this case thrust is generated by a propeller with multiple (usually six or more) blades of exceptionally thin profile, sharp edges and a curved scimitar-like planform. For highest efficiency two such propellers counter-rotate. The propellers may be open or shrouded. Such an engine gives turboprop economy at jet speed. As a high-speed version of a turboprop, the propfan has all the advantages of a turboprop, with significantly higher power output. Most propfans are being developed in the Ukraine or Russia and employ state-of-theart technology.

Thrust is usually controlled by a combination of the fuel flow and the pitch of the propeller blades, leaving the engine rotational speed relatively constant. This provides an advantage because thrust, or airflow, can be changed more quickly than with other aircraft engines. As mentioned previously, almost all exhaust gas energy is consumed by the power turbine, making exhaust gas management more tractable. U.S. Turbine Corp. ${ }^{20}$ indicates that in industrial 
applications the exhaust from turboshaft engines is commonly ducted away with simple stainless steel ductwork. This removes the difficulty of overheating the airflow encountered with turbofans.

\subsection{Candidates}

Table D-2 in Appendix D shows the turboprop and propfan engines currently in development, production, or available as used from around the world. It is readily apparent that almost all high-power turboprop engine development is being performed in former Soviet bloc countries. Only two are manufactured in the U.S.: the Allison T56 and AE 2100. Costs for turboprop engines range from $\$ 75 / \mathrm{kW}$ for the Kuznetsov NK-12MV to $\$ 360 / \mathrm{kW}$ for the AE 2100 .

\subsubsection{U.S.-Made Turboprops}

The Allison T56 series (Figure 4) has a long and distinguished record, serving as the powerplant of aircraft such as the Lockheed C-130 "Hercules" transport and variants since 1954. Power output ranges from 3,700 shaft horsepower (shp) in earlier models, to 4,500 shp in later models. One variant, the A-427, attained $5200 \mathrm{shp}$. Currently, the U.S. military is upgrading to the " $\mathrm{J}$ " series of the C-130, which employs the newer AE 2100 engine. Therefore, in early 1997, Allison ${ }^{21}$ discontinued production of the T56 in favor of the AE 2100, and no longer has any T56 models available. In production, the T56 cost approximately $\$ 800,000$ per unit. The WSC would require an array of 90 T56 engines to meet the expected peak power requirement.

The first Allison AE 2100 completed flight testing in 1990, making it the newest production turboprop available today. The engine produces thermodynamic power of $6,000 \mathrm{hp}$; however, all models currently in production have been derated to between $3,200 \mathrm{shp}$ and $4,500 \mathrm{shp}$. The $\mathrm{C}-130 \mathrm{~J}$ program employs the $\mathrm{AE}$ 2100D3 model, flat rated at 4,591 shp, with a Dowty Aerospace six-bladed R391 propeller. Cost is reported by Allison to be approximately $\$ 1.2 \mathrm{M}$ per unit, not including propellers.

It is not known whether a $6,000 \mathrm{shp}$ rated version will be available in time to support the WSC. 68-6,000 shp engines or 90-4,500 shp engines would be required to meet the WSC peak power demand.

\subsubsection{Russian-Made Turboprops}

The Kuznetsov NK-12MV (Figure 5) is a large counter-rotating turboprop engine, in service in various configurations with the former Soviet Union for approximately 40 years. It is the most powerful conventional turboprop

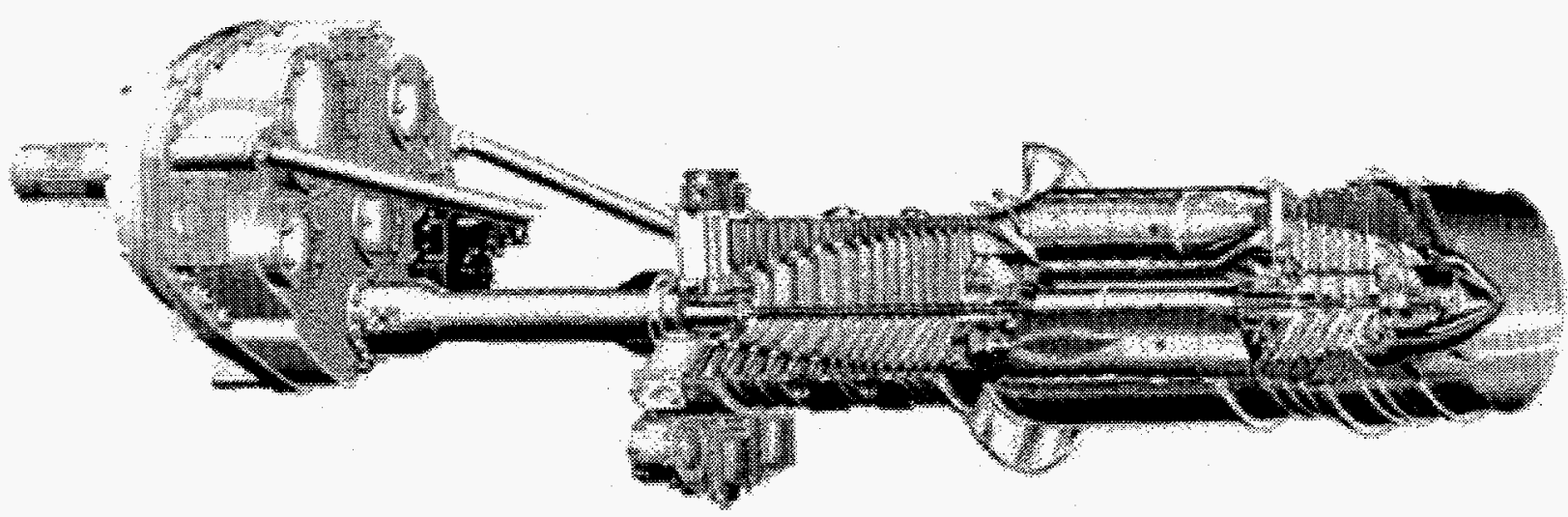

Figure 4. Cutaway view of the Allison T56. 


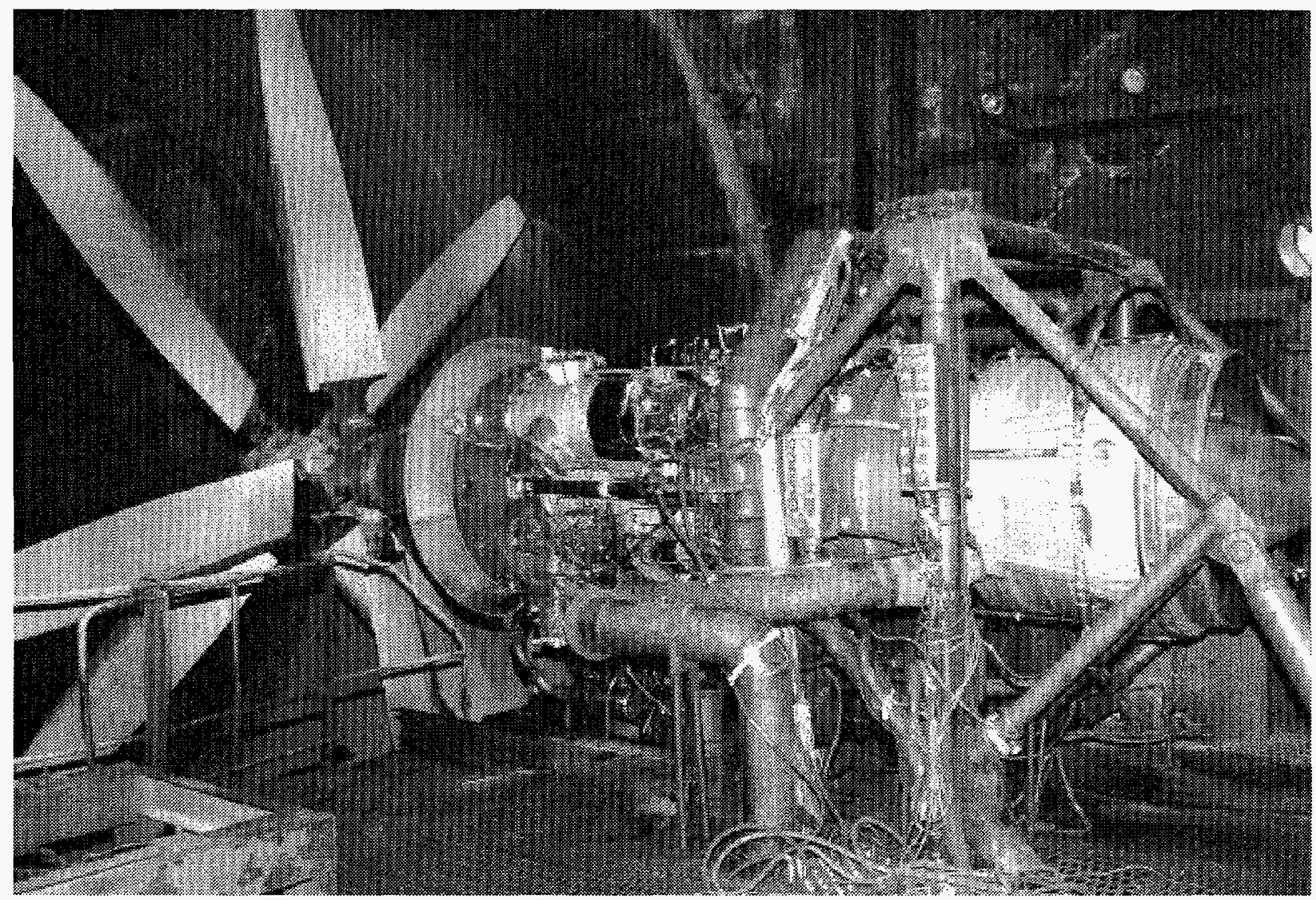

Figure 5. NK-12MV on test stand.

aircraft engine in the world, rated at $14,750 \mathrm{shp}$. Variants of this engine- - up to $30,000 \mathrm{shp}$-have been built for powerplant and pipeline pumping applications.

At $14,750 \mathrm{shp}, 28$ units would be required to meet the predicted WSC peak power demand.

The MV design has been used extensively on both military and civil aircraft. Typically, a $6.2 \mathrm{~m}(20 \mathrm{ft}-4 \mathrm{in}$.) reversible pitch propeller set is used in military applications, while civilian applications employ a $5.6 \mathrm{~m}$ ( $18 \mathrm{ft}-4 \mathrm{in}$.) propeller set. All propeller configurations employ two sets of four variable pitch blades on independent counter-rotating coaxial shafts (The counterrotating and independent nature of the propellers is appealing in this application because it provides a simple means of controlling the vorticity and subsequent lateral turbulence content of the airflow).
The NK12-MV also has prior experience as a wind tunnel main drive. Kuznetsov factory representatives ${ }^{22}$ report that a wind tunnel was built to test the NK93 propfan (discussed below) that was driven by a single NK12-MV. This effort produced valuable data on engine ground test properties including propeller behavior, reliability data, and operating costs. Some effort will be required to predict life cycle costs for U.S.-based operation from the Russian-based cost data.

The problem of noise with turboprop engines appears to be exacerbated somewhat in the NK-12. Factory reported sound pressures for indoor operation reach $143 \mathrm{~dB}$ at the engine outlet. While engine outlet noise would be significantly reduced by ducting the exhaust out of the airflow, further effort will be required to determine whether engine noise would affect WSC operations. 
It is reported that this engine has been modified to burn natural gas rather than liquid jet fuel with positive results. This modification requires replacement of fuel orifices, fuel pipelines, and fuel delivery controllers.

Information from the U.S. Defense Technical Information Center and extrapolation to include civilian applications indicate that in excess of 3,000 NK-12MV series engines have been produced. Ongoing disarmament activities have caused a large supply of these engines to be available, however, firm data is not yet available on the delivery time for 28 units.

The Dvigatel NK-93 is the most powerful propfan known to be under development anywhere in the world. This engine generates 22.4 MW (30,000 shp), which is over twice the power output of the NK-12MV. The NK-93 has a front fan with 8 blades ( $40 \%$ power) and a rear fan with 10 blades ( $60 \%$ power) which counterrotate similar to the NK-12 turboprop. The high power of the NK-93 points to an array one-half the size of the preliminary design.
Unfortunately, this and other large propfans are still in development phase and not ready for production at this time. The designer indicates that, because of a protracted budget shortfall, development will continue to lag behind schedule, and the engine will not enter production in time to support this program.

\subsection{Summary}

Table 3 summarizes the analysis of turboshaft engines as main drive candidates. The system-installed cost of the candidates shows a very large range: from $\$ 32 \mathrm{M}$ to $\$ 221 \mathrm{M}$. This range reflects the difference between the NK$12 \mathrm{MV}$ and its lighter, flight optimized American counterparts. The use of turboprop engines is attractive for a variety of reasons: high power output, direct drive compatibility, long service history, and low cost. Although the most attractive candidates are manufactured overseas, a U.S. supplier has been identified ${ }^{23}$ to develop and deliver complete main drive systems from the basic engines.

Table 3. Summary evaluation of turboshaft aircraft engines.

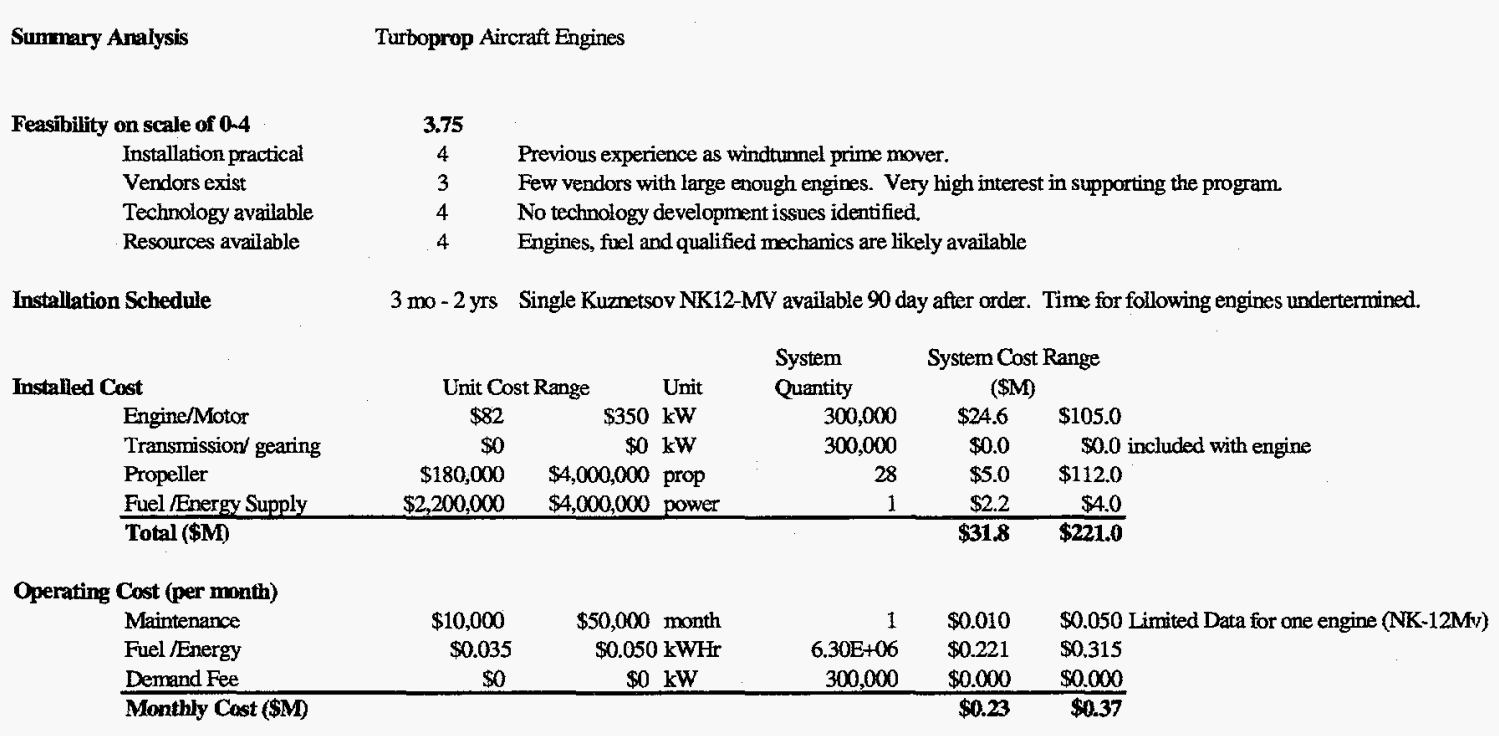




\section{INDUSTRIAL TURBOSHAFT ENGINES}

\subsection{Description}

Industrial turboshaft engines, or gas-turbines (Figure 6), are ground-based derivatives of aircraft turbofan or turboprop engines.

Employed in a wide variety of mechanical drive and power production applications, they feature high power, high efficiency, low exhaust emissions, and installation flexibility. Table D-3 in Appendix D shows a sampling of gas-turbines on the market. ${ }^{13}$ Many of the engines surveyed are designed to operate on either liquid or natural gas fuels, further enhancing their flexibility.

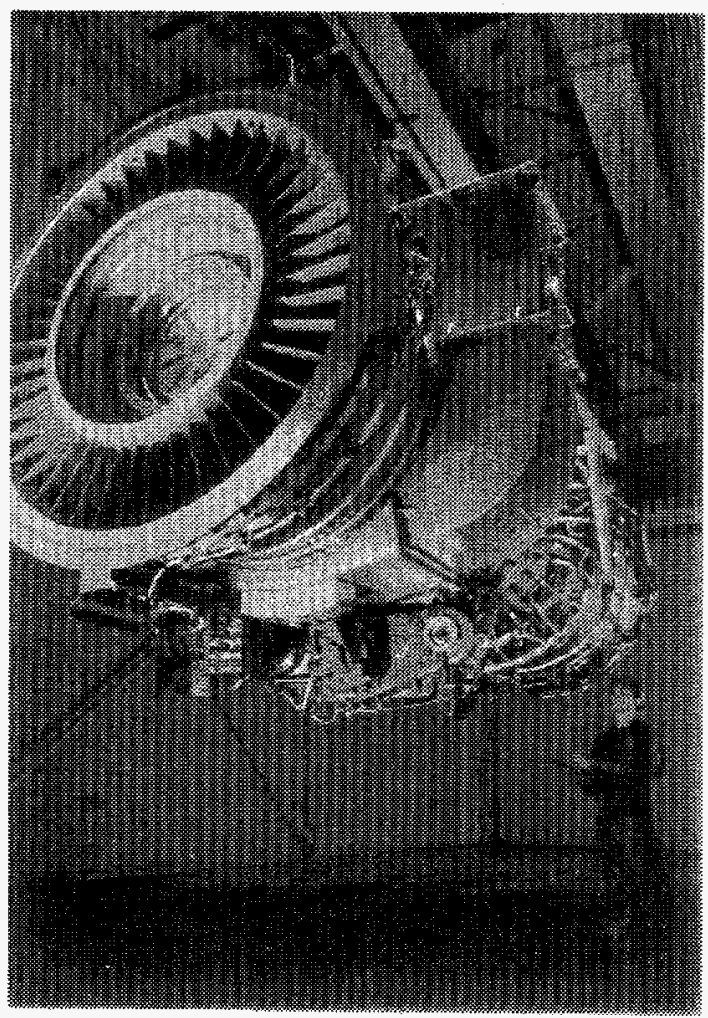

Figure 6. The 45 MW GE LM6000 gas turbine engine

\subsection{Application}

The application of gas turbine engines is quite flexible. They may be installed in a remote drive configuration as with electric motors, or, depending on engine and gearbox dimensions, they may be set up in a direct drive configuration. The availability of engines over a wide power output range would simplify the design of the main drive array, and the balance of the WSC. Drive gears and propeller sets would be specially designed and built to match the operating characteristics particular to the selected engine. Because these engines are designed to operate at constant speed, airflow speed control would require variable pitch propellers. As noted in Section 4.3, this technology is readily available and would not add significantly to the system cost. Infrastructure costs would be similar to those enumerated in Section 6.2 for turbofan engines.

To our knowledge, gas turbines have not been used in a wind tunnel application. It is therefore difficult to estimate the life cycle costs for the unique application envisioned for the WSC.

\subsection{Summary}

Gas turbine engines appear to be well suited for this application. They offer the power, compact size, low exhaust emissions, and application flexibility to facilitate the design, permitting, construction, and operation of the WSC. Countering these advantages are the lack of history in this application, high initial cost, and long lead time to procure. The specific cost $(\$ / \mathrm{kW})$ of these systems is 3 to 5 times greater than that for select aircraft turboshaft engines, while delivery time is constrained by propeller design and fabrication to two years (Table 4).

\section{CONCLUSIONS}

\subsection{Feasibility}

The aircraft turbofan is the only candidate determined to be infeasible for this application. While it would be possible to overcome the exhaust temperature and power cycling issues, the cost and development time associated with the effort would be similar to that for a new 
Table 4. Summary evaluation of industrial gas turbine engines.

$\begin{array}{lcl}\text { Summary Analysis } & \text { Industrial Gas Turbines } \\ \begin{array}{c}\text { Feasibility on scale of 0-4 } \\ \text { Installation practical }\end{array} & 3.5 & \\ \text { Vendors exist } & 3 & \text { Installation and operation similar to electric motors, speed control may be an issue } \\ \text { Technology available } & 3 & \text { Several vendors exist. Those contacted show interest in supporting this project } \\ \text { Resources available } & 4 & \text { May require cycling engine speed to change flow rate } \\ \text { Availability } & & \\ & 2 \text { years } & \text { Limited by propellers and reduction gears }\end{array}$

\begin{tabular}{crrrrrr} 
& \multicolumn{1}{c}{} & \multicolumn{2}{c}{ System } & \multicolumn{2}{c}{ System Cost Range } \\
Installed Cost & Unit Cost Range & Unit & Quantity & \multicolumn{1}{c}{$\mathbf{\$ M})$} \\
Engine/Motor & $\$ 250$ & $\$ 350 \mathrm{~kW}$ & 300,000 & $\$ 75$ & $\$ 105$ \\
Transmission/ gearing & $\$ 10$ & $\$ 15 \mathrm{~kW}$ & 300,000 & $\$ 3$ & $\$ 5$ \\
Propeller & $\$ 3,000,000$ & $\$ 4,000,000$ & prop & 20 & $\$ 60$ & $\$ 80$ \\
Fuel /Energy Supply & $\$ 2,200,000$ & $\$ 4,000,000$ & power & 1 & $\$ 2$ & $\$ 4$ \\
\hline Total & & & & & $\$ 140$ & $\$ 194$
\end{tabular}

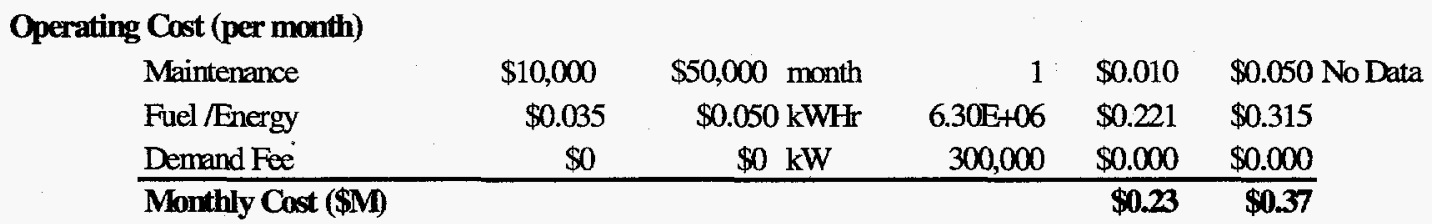

Assumptions:

20 - 15MW motors driving array of 20 fans @ 2.9 million cfm each

Run time 30 hours/month at an average of $70 \%$ full power: $6,300,000 \mathrm{kWhr} / \mathrm{month}$

product line, and not compatible with the construction schedule of the WSC. Turbofans will not be discussed in the comparisons to follow.

The remaining candidates-electric, aircraft turboprop, and industrial turboshafts-are all technically feasible. However, they differ in the quantity of technical development required, and the risk associated with the development effort.

The use of electric motors would not be simple for this particular application. Current motor control technology appears to have a power limit of 7.5 MW, above which development would become much more involved. The real limitation, however, appears to be the infrastructure requirements to deliver power to the system. The WSC's large predicted power demand, combined with the proposed site location relative to major power sources, make the cost of power prohibitive. Electric motors rank third in this category.

Aircraft turboshafts are well suited to this application. No significant modifications are necessary prior to installation. And the systems are well understood: they have logged millions of hours coupled with the gears and propeller sets that would be used in the WSC. The NK-12 has prior application as a wind tunnel main drive. This historical information would facilitate the prediction and solution of installation issues and maintenance requirements, and improve the accuracy of predicted lifecycle costs. Aircraft turboshafts rank first in this category. 
Industrial turboshaft engines also appear to be well suited for this application. While no obstacles or significant modifications are foreseen, this would be a novel application for these systems, and a learning curve can be expected in developing appropriate propeller sets and operating parameters. Thus, industrial engines rank second in feasibility.

\subsection{Availability}

Electric motors will depend upon the electric power delivery infrastructure, which has been predicted to take as long as 3 years. Aircraft turboshafts have a distinct advantage in availability. Because the engines, gears, and propellers are currently extant and in storage, the delivery time for a single fully operational engine is advertised to be six months. Gas turbines are constrained by design and fabrication of the propellers, which could take up to 2 years. Thus aircraft turboshafts lead this category, followed by industrial engines and electric motors.

\subsection{Power}

In the category of power output, electric motors again rank third. While it is theoretically possible to build electric motors in any size, current controller technology appears to set a practical upper bound of about 7.5 MW per unit.

Industrial gas turbines not only provide the most power of any of the candidates, but also provide a wide range of options, from less than 1 to over $50 \mathrm{MW}$ output. This range provides great flexibility in the facility design, allowing the selection of unit power after the balance of the facility has been designed and characterized. This flexibility earns a first place ranking.

Aircraft turboprops do not exhibit the power range of industrial engines. The maximum is represented by the NK-12MV at $11 \mathrm{MW}$, earning a rank of second.

\subsection{Installed Cost}

In general, all systems investigated would cost between $\$ 250 / \mathrm{kW}$ and $\$ 350 / \mathrm{kW}$, plus supporting infrastructure costs. Infrastructure for an electric system was calculated to be $\$ 30-\$ 40 \mathrm{M}$, while that for liquid fueled systems was $\$ 2$ $\$ 4 \mathrm{M}$. An exception to this trend was the NK$12 \mathrm{MV}$ aircraft turboshaft, costing less than $\$ 100 / \mathrm{kW}$ with the propellers included. The installed cost for an array of these units is estimated to be $\$ 32 \mathrm{M}$ (Table 3), while the next candidate, industrial gas turbines, will cost a minimum of $\$ 140 \mathrm{M}$ (Table 4). Thus aircraft turboprops rank first, followed by industrial turboshafts and electric motors.

\subsection{Operating Cost}

Operating cost data, as shown in the summary tables, is currently limited to estimated fuel/energy costs based on a fixed output per month. While reliability information is available for some extant candidates (Appendix E), it is difficult to meaningfully extrapolate what the reliability of novel combinations of engine/ motor/gear/propeller might be. Therefore, ranking is not performed in this category.

\subsection{Rank}

Aircraft turboshaft engines are ranked first overall, having earned first in the categories of feasibility, availability, and installed cost, and second in power. This ranking is almost entirely due to the remarkable combination of attributes found in the NK-12MV.

Industrial turboshaft engines rank second, having placed first in power, and second in all other categories.

Electric motors are third choice, being a feasible, but difficult and expensive solution for this application.

Finally, aircraft turbofans are ranked last, as they do not appear to be a viable option. 


\subsection{Recommendations}

In the course of this investigation the remarkable attributes of NK-12MV have become readily apparent. These units have a long service history, both in the air and on the ground, with good reliability statistics (Appendix E). They are already built, and can be overhauled and begin delivery to the WSC site within months, rather than years. They produce very respectable power, at $11.2 \mathrm{MW}$ each, and run relatively cool, simplifying exhaust management. Finally, the installed cost for these units is approximately $\$ 110 \mathrm{M}$ less than the next alternative.

However, more detailed information about the operational characteristics, maintenance, and life cycle cost must be ascertained prior to the final decision to employ this unit as the WSC main drive.
It is recommended that

1. An in-depth investigation of the NK$12 \mathrm{MV}$ be initiated, including groundbased operating characteristics, life cycle costs, and availability.

2. WSC analysis, design, and project management studies assume a main drive system composed of NK-12MV units until the recommended detailed analysis substantiates the unit's suitability for this application.

3. If further investigation reveals that the NK-12MV is not suitable, then the industrial turboshaft engine should be investigated as the next logical choice

4. Finally, the possibility of a hybrid system should be explored. In this case, a core of 2-4 electric motor driven fans might be placed in the center of the array, providing airflow for checkout and lowspeed tests. This arrangement would avoid the large infrastructure costs of a purely electric system, while allowing a simple and rapid means of performing low velocity tests, calibration, and instrument check-out. 


\section{REFERENCES}

1. Idaho National Engineering and Environmental Laboratory, Conceptual Design Report, PNDR Partnership for Natural Disaster Reduction Test Complex Phase 1, INEL/EXT-97-00436, May 7, 1997.

2. INEEL, "Program Plan for the Partnership for Natural Disaster Reduction," Draft, January 1998.

3. C. C. O’Brien, "Full-Scale Structural Testing for Severe Wind, 1995," INEL-96/0123, May 1996.

4. J.E. Beavers, Chair, "Report on Wind and Earthquake Facility Needs," IMMP Committee on Wind and Earthquake Facility Needs, Draft, January 1996.

5. Bill Gunston, Editor, Jane's Aero-Engines, Jane's Information Group Inc., 1996.

6. Dave Johnston, New Philadelphia Fan Co., October 1997.

7. Bill Clifton, Philadelphia Gear Corp., King of Prussia, PN, September 1997.

8. W. H. Rae, Jr., and A. Pope, Low Speed Wind Tunnel Testing, 2nd Ed., John Wiley \& Sons, Inc., New York, 1984.

9. E. A. Avallone, and T. Baumeister, III, Marks' Standard Handbook for Mechanical Engineers, Eighth Edition, McGraw-Hill Book Co., New York, 1978.

10. Lew Brown, GE Motors and Industrial Systems, Denver, CO, August 1997.

11. Ron Shelburg, Idaho Power Planning Department, Boise, ID, March 1997.

12 Kent McCarthy, Idaho Power Planning Department, Boise, ID, July 1997.

13. Turbine Systems Engineering, Inc., 205 S. Broadway, Coweta Ok. 74429, Tel: 918-486-3085, Fax:918-486-6290, http://www.gas-turbines.com/

14. Keith Long, GE Power Systems, Salt Lake City, UT, July 1997.

15. John Dearien, Idaho National Engineering and Environmental Laboratory, August 1997.

16. Rick Moore, Intermountain Gas Company, Pocatello, ID, December 1997.

17. Mike Mohageh, Boeing (Structures Division), Seattle, WA, July 1997.

18. Doug Baird, GE Aircraft Parts, Cincinnati, OH, July 1997.

19. Joel Gissendanner, Pratt \& Whitney, CN, July 1997.

20. Charles Brown, U.S. Turbine Corp., Mainville, OH, March 1997. 
21. Dean Mosser, Allison Engine Co., Indianapolis, IN, November 1996.

22. Valentin Ovchinnikov, Samara Machine-building Design Bureau, Samara, Russia, December 1996.

23. Bosch Aerospace, Letter to J. M. Lacy, "High Power Fans for Wind Tunnel Applications," 18 July 1997. 
Appendix A

Conceptual Windstorm Simulation Center Main Drive Power Calculations 


\section{Wind Tunnel Flow Losses and Power Requirements}

4/1/97

J. M. Lacy

\section{References:}

Rouse, H., Elementary Mechanics of Fluids, Dover Publications, Inc., New York, 1946.

Rae, W. H. Jr., and Pope, A., Low Speed Wind Tunnel Testing, 2nd Ed. John Wiley \& Sons, New York, 1984.

\section{Design Parameters :}

Max airflow speed at test section

Jet Width

Jet Height

$$
\begin{aligned}
& \mathrm{v}_{\text {test }} \equiv 200 \cdot \mathrm{mph} \\
& \mathrm{w}_{\text {jet }} \equiv 80 \cdot \mathrm{ft} \\
& \mathrm{H}_{\text {jet }} \equiv 40 \cdot \mathrm{ft} \\
& \eta:=80 \cdot \%
\end{aligned}
$$

Propeller efficiency

\section{Assumptions, Definitions, and Properties:}

Intake air is still

Incompressible fluid flow

Density of air $\quad \gamma:=11.8 \cdot \frac{\text { newton }}{\mathrm{m}^{3}}$

Dynamic Viscosity $(T=80 \mathrm{~F})$

Units:

\section{Section Definitions (see attached figure)}

Volume 1: Bell mouth contraction to fans

Volume 2: Fan exit contraction to jet

\begin{tabular}{|c|c|c|c|}
\hline Test Section Area & $A_{\text {test }}:=W_{\text {jet }} H_{\text {jet }}$ & $A_{\text {test }}=297.29 \cdot \mathrm{m}^{2}$ & $A_{0}:=A_{\text {test }}$ \\
\hline & & $\mathrm{V}_{\text {test }}=89.408 \cdot \frac{\mathrm{m}}{\mathrm{sec}}$ & $\mathrm{V}_{0}:=\mathrm{V}_{\text {test }}$ \\
\hline Volumetric Flow Rate & $\mathrm{Q}:=\mathrm{A}_{\text {test }} \cdot \mathrm{V}_{\text {test }}$ & $\mathrm{Q}=2.658 \cdot 10^{4} \cdot \frac{\mathrm{m}^{3}}{\mathrm{sec}}$ & \\
\hline Jet Dynamic Pressure & $\mathrm{q} 0:=\left[\frac{1}{2} \cdot \rho \cdot\left(\mathrm{V}_{\text {test }}\right)^{2}\right.$ & $\mathrm{q} 0=4.809 \cdot \mathrm{kPa}$ & \\
\hline
\end{tabular}

Volume 0: High bay/test section flow

Section 3: High bay exhaust to ambient

\section{Test Section Characteristics}




\section{Velocity Profile through Tunnel}

Bellmouth entrance (1)

$$
\mathrm{V}_{1}:=50 \cdot \mathrm{mph}
$$

$$
A_{1}:=\frac{Q}{V_{1}}
$$

$\mathrm{A}_{1}=1.189 \cdot 10^{3} \cdot \mathrm{m}^{2}$

$\sqrt{A_{1}}=113.137 \cdot f t$

Entrance to Fans (2)

Assume an array of $20^{\prime}$ Diameter fans. Exit area is equal to array of $20^{\prime}$ squares:

$N_{\text {fan }}:=28$
$A_{2}:=N_{f a n} \cdot 400 \cdot \mathrm{ft}^{2}$
$A_{2}=1.041 \cdot 10^{3} \cdot \mathrm{m}^{2}$
$\mathrm{V}_{2}:=\frac{\mathrm{Q}}{\mathrm{A}_{2}}$
$\sqrt{A_{2}}=105.83 \cdot f t$

High Bay

Open Section Area is normally $4 x$ the jet area:
$A_{3}:=4 \cdot A_{0}$
$A_{3}=1.189 \cdot 10^{3} \cdot \mathrm{m}^{2}$
$V_{3}:=\frac{Q}{A_{3}}$
$\sqrt{A_{3}}=113.137 \cdot f t$

Equivalent Diameter of Sections

$\mathrm{D}:=\sqrt{4 \cdot \frac{\mathrm{A}}{\pi}}$

$$
\mathrm{D}=\left[\begin{array}{l}
19.456 \\
38.911 \\
36.398 \\
38.911
\end{array}\right] \cdot \mathrm{m}
$$

$$
\mathrm{V}=\left[\begin{array}{l}
89.408 \\
22.352 \\
25.545 \\
22.352
\end{array}\right] \cdot \frac{\mathrm{m}}{\mathrm{sec}}
$$

\section{Energy Loss By Section and Volume}

\section{Bellmouth entrance (section 1)}

Loss Coefficient $\quad C_{L_{1}}:=0.35$

$$
\begin{array}{lll}
\text { Pressure Drop } & \Delta \mathrm{p}_{1}:=\gamma \cdot \mathrm{C}_{\mathrm{L}_{1}} \cdot \frac{\left(\mathrm{V}_{2}\right)^{2}}{2 \cdot \mathrm{g}} & \Delta \mathrm{p}_{1}=0.137 \cdot \mathrm{kPa} \\
& \mathrm{K}_{0_{1}}:=\frac{\Delta \mathrm{p}_{1}}{\mathrm{q} 0} & \mathrm{~K}_{0_{1}}=0.029
\end{array}
$$

\section{Contraction from Fans to Jet (volume 2)}

Section Length

Avg Velocity

Characteristic Length

Reynold's No.
$\mathrm{L}_{\mathrm{sec}}:=190 \cdot \mathrm{ft}$

$$
\mathrm{V}_{\text {avg }}:=\frac{\mathrm{V}_{0}+\mathrm{V}_{2}}{2} \quad \mathrm{~V}_{\text {avg }}=57.477 \cdot \frac{\mathrm{m}}{\mathrm{sec}}
$$$$
\mathrm{L}=27.927 \cdot \mathrm{m}
$$

$\mathrm{L}:=\frac{\mathrm{D}_{2}+\mathrm{D}_{0}}{2}$

$$
\mathrm{R}:=\frac{\rho}{\mu} \cdot \mathrm{V}_{\text {avg }} \cdot \mathrm{L}
$$

$R=1.048 \cdot 10^{8}$

Skin Friction (Table Lookup based on R, Rouse)

$\mathrm{K}_{\mathrm{O}_{2}}:=\frac{0.32 \cdot \lambda \cdot \mathrm{L}_{\mathrm{sec}}}{\mathrm{D}_{0}} \quad \mathrm{~K}_{\mathrm{O}_{2}}=9.525 \cdot 10^{-4}$

$\Delta \mathrm{p}_{2}:=\mathrm{K}_{\mathrm{O}_{2}} \cdot \mathrm{q} 0 \quad \Delta \mathrm{p}_{2}=0.005 \cdot \mathrm{kPa}$ 
Jet Losses in open test section

$$
\begin{array}{lc}
\mathrm{L}_{\mathrm{sec}}:=160 \cdot \mathrm{ft} & \\
\lambda:=0.08 & \text { From Rae \& Pope } \\
\mathrm{K}_{\mathrm{O}_{0}}:=\frac{\lambda \cdot \mathrm{L}_{\mathrm{sec}}}{\mathrm{D}_{0}} & \mathrm{~K}_{\mathrm{O}_{0}}=0.201 \\
\Delta \mathrm{P}_{0}:=\mathrm{K}_{\mathrm{O}_{0}} \cdot \mathrm{q0} & \Delta \mathrm{Q}_{0}=0.964 \cdot \mathrm{kPa}
\end{array}
$$

High Bay Exhaust to Ambient (section 3)

$$
\mathrm{C}_{\mathrm{L}_{3}}:=1.0
$$

$\Delta p_{3}:=\gamma \cdot C_{L_{3}} \cdot \frac{\left(V_{0}\right)^{2}}{2 \cdot g}$

$\Delta \mathrm{p}_{3}=4.809 \cdot \mathrm{kPa}$

$\mathrm{K}_{\mathrm{O}_{3}}:=\frac{\Delta \mathrm{p}_{3}}{\mathrm{q} 0}$

$\mathrm{K}_{0_{3}}=1$
Note: This assumes the length of high bay is not enough to extract much energy. Therefore loss is calculated assuming full jet velocity.

\section{Summary of Losses}

Total Pressure Drop

$\Delta \mathrm{p}=\left[\begin{array}{l}0.964 \\ 0.137 \\ 0.005 \\ 4.809\end{array}\right] \cdot \mathrm{kPa}$

$\Sigma_{\Delta p}=5.916 \cdot \mathrm{kPa}$
Total Loss Coefficient

$\mathrm{K}_{0}=\left[\begin{array}{l}0.201 \\ 0.029 \\ 9.525 \cdot 10^{-4} \\ 1\end{array}\right]$

$\sum \mathrm{K}_{0}=1.23$
Tunnel Energy Ratio

$$
\begin{aligned}
& \mathrm{ER}:=\frac{1}{\sum \mathrm{K}_{0}} \\
& \mathrm{ER}=0.813
\end{aligned}
$$

Composite Energy Ratio

$\mathrm{ER}_{\text {comp }}:=\eta \cdot \mathrm{ER}$

$\mathrm{ER}_{\text {comp }}=0.65$ 


\section{Static Pressure Profile Through Tunnel}

$$
\begin{aligned}
& \mathrm{P}_{\mathrm{atm}}:=1 \cdot \mathrm{atm}-\gamma \cdot 5000 \cdot \mathrm{ft} \quad \mathrm{P}_{\mathrm{atm}}=83.342 \cdot \mathrm{kPa} \\
& \mathrm{v}_{\mathrm{atm}}:=0 \cdot \frac{\mathrm{m}}{\sec } \\
& \frac{\mathrm{v}_{1}^{2}}{2 \mathrm{~g}}+\frac{\mathrm{p}_{1}}{\gamma}+\mathrm{z}_{1}+\mathrm{h}_{\mathrm{p}}=\frac{\mathrm{v}_{2}^{2}}{2 \mathrm{~g}}+\frac{\mathrm{p}_{2}}{\gamma}+\mathrm{z}_{2}+\mathrm{h}_{1} \mathrm{D} \\
& \mathrm{p}_{0}:=\left[\mathrm{v}_{\mathrm{atm}}{ }^{2}-\left(\mathrm{v}_{0}\right)^{2}\right] \cdot \frac{\rho}{2}+\mathrm{P}_{\mathrm{atm}}+\Delta \mathrm{p}_{3}+\Delta \mathrm{p}_{0} \quad \mathrm{p}_{0}=84.306 \cdot \mathrm{kPa} \\
& \mathrm{p}_{2}:=\left[\mathrm{v}_{\mathrm{atm}}{ }^{2}-\left(\mathrm{V}_{2}\right)^{2}\right] \cdot \frac{\mathrm{p}}{2}+\mathrm{P}_{\mathrm{atm}}+\Delta \mathrm{p}_{0}+\Delta \mathrm{p}_{2}+\Delta \mathrm{p}_{3} \quad \mathrm{p}_{2}=88.728 \cdot \mathrm{kPa} \\
& \mathrm{p}_{1}:=\left[\mathrm{P}_{\mathrm{atm}}+\left[\mathrm{v}_{\mathrm{atm}}^{2}-\left(\mathrm{V}_{2}\right)^{2}\right] \cdot \frac{\rho}{2}\right]-\Delta \mathrm{p}_{1} \quad \mathrm{p}_{1}=82.812 \cdot \mathrm{kPa} \\
& \text { Fan Power: } \quad P:=\frac{\left(P_{2}-p_{1}\right) \cdot Q}{\eta} \quad P=196.551 \cdot M W \quad P=2.636 \cdot 10^{5} \cdot h p \\
& \text { Required Shaft Power per Fan: } \quad P_{\text {fan }}:=\frac{P}{N_{\text {fan }}} \quad P_{\text {fan }}=9.414 \cdot 10^{3} \cdot h p
\end{aligned}
$$


A review of the literature indicates that an Energy Ratio greater than 0.5 may be difficult to achieve.

Examine the power required assuming the composite ER ranges between 0.3 and 0.8

ER : $=0.3,0.325 . .1 .5$

Required Composite Power

$P(E R):=\frac{.5 \cdot \rho \cdot A_{\text {test }} \cdot V_{\text {test }}^{3}}{E R} \quad P(0.5)=255.664 \cdot M W$

Required Shaft Power per Fan:

$P_{\text {fan }}(E R):=\frac{P(E R)}{N_{\text {fan }}}$

$\mathrm{P}_{\text {fan }}(0.5)=9.131 \cdot \mathrm{MW}$

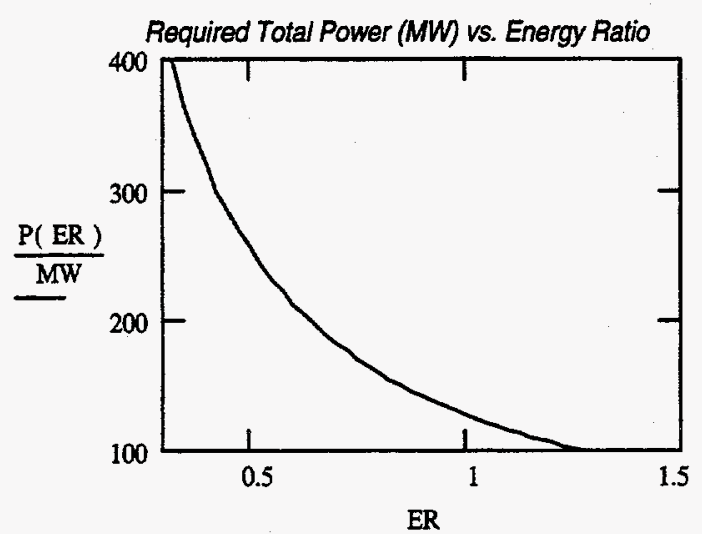

Required individual fan power (MW) vs, energy ratic assuming 28 fan array

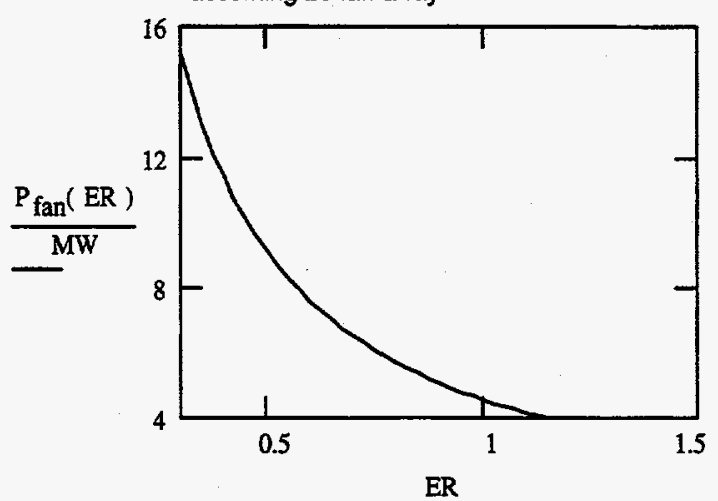

The design baseline assumes the use of 28 Kuznetsov NK-12MV turboprop engines. These engines are rated at $14750 \mathrm{shp}(11.0 \mathrm{MW})$ each. Therefore this configuration can be expected to deliver the required jet velocities for energy ratios down to approximately 0.4. Design enhancements, such as the addition of an exhaust diffuser, that increase the composite ER from 0.4 to, for example 0.55 , would decrease power requirements by $87 \mathrm{MW}$. 
Power required as a function of energy ratio and jet velocity

$P(E R, V):=\frac{.5 \cdot \rho \cdot A_{\text {test }} \cdot v^{3}}{E R}$

Test section area

$A_{\text {test }}=297.29 \cdot \mathrm{m}^{2}$

$\mathrm{V}:=50 \cdot \frac{\mathrm{m}}{\mathrm{sec}} .100 \cdot \frac{\mathrm{m}}{\mathrm{sec}}$

Composite power vs. test section velocity at energy ratios of $0.4,0.6$, and 0.8

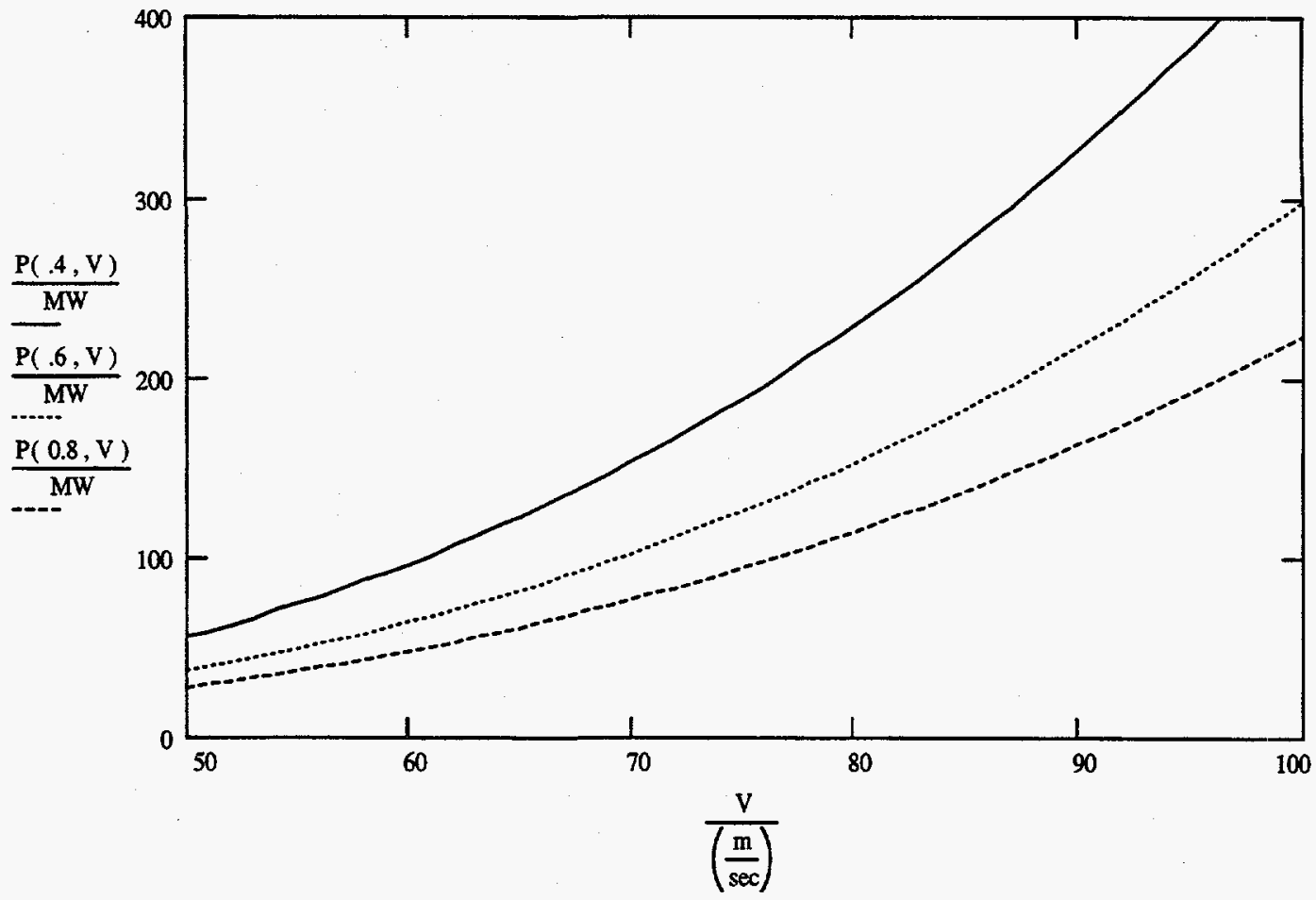


Appendix B

Request for Information Commerce Business Daily 
[Commerce Business Daily: Posted June 17, 1997]

From the Commerce Business Daily Online via GPO Access

[cbdnet.access.gpo.gov]

PART: U.S. GOVERNMENT PROCUREMENTS

SUBPART: SUPPLIES, EQUIPMENT AND MATERIAL

CLASSCOD: 99-Miscellaneous-Potential Sources Sought

OFFADD: Lockheed Idaho Technologies Company, P.O. Box 1625, Falls, ID 83415-3521

SUBJECT: 99-HIGH POWER FANS FOR WIND TUNNEL APPLICATION

SOL cbdO78

DUE 071897

POC Jeff Lacy

DESC: Lockheed Martin Idaho Technologies Company (LMITCO), a management and operating contractor for the Department of Energy (DOE) at the Idaho National Engineering \& Environmental Laboratory (INEEL) is seeking sources only. There is no solicitation available. The Idaho National Engineering and Environmental Laboratory is developing a design for a large-scale structural wind test facility as a critical activity of the Partnership for Natural Disaster Reduction. The conceptual design for this facility is an open-circuit, open-test section wind tunnel, with fans mounted in an array upstream of the test section. An airflow of $90 \mathrm{~m} / \mathrm{s}$ is required over a throat area of 300 sq. meters. It is estimated that between 250 and $300 \mathrm{MW}$ will be required to provide this airflow, subject to design optimization of the facility. Current schedule will require delivery of fan system in early 2000 . Sources are sought for candidate propulsion systems to provide the described airflow. There is currently no restriction on type of power source, however, the ability to prescribe and vary the longitudinal large scale turbulence produced is required. It is expected that an array of fans will be employed, with numerical limits imposed by control and maintenance issues. Interested firms with either pre-existing or proposed design solutions are invited to respond within 30 days of this notice. Responses should include candidate physical dimensions, power, efficiency and reliability and maintainability statistics, as available.

LINKURL: http://www.inel.gov/procurement/litco/index.html

LINKDESC: LMITCO Procurement area

EMAILADD: lcy@inel.gov

EMAILDESC: Jeff Lacy

CITE: (W-168 SN085782) 
Appendix C

List of Contacts 


\section{Appendix C}

\section{Contact List}

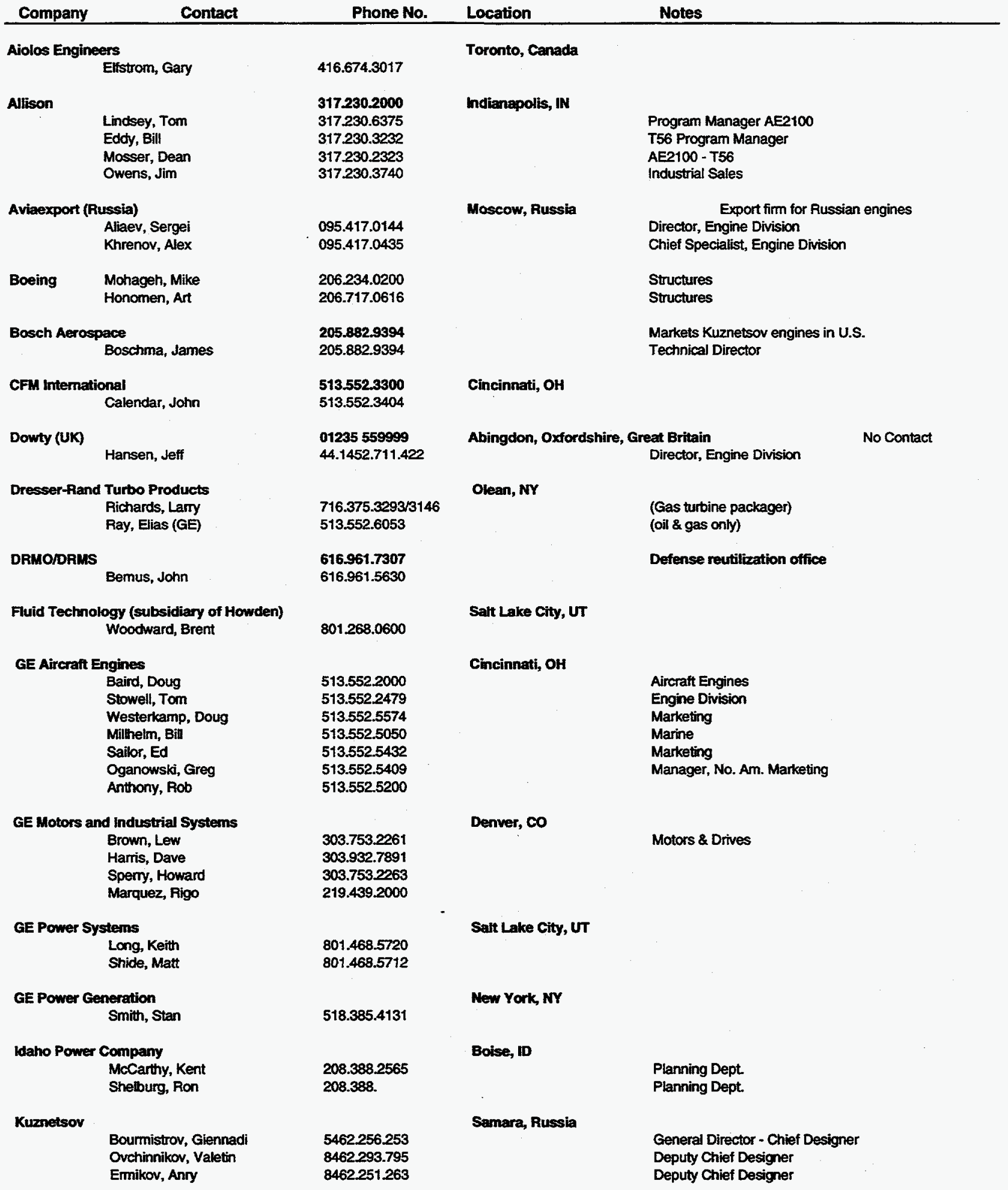


Lockheed Martin Aeronautical Systems

Searle, Nom

Kays, Steve

Bangert, Lou

Dupack, Joe

Pounds, Gerald

Perry, Mark

Lockheed Martin Astronautical Systems

Giere, David

Parsons, Don

70.494 .0938

770.494 .7338

770.793 .0049

770.494 .8472

770.494 .4158

770.494 .5619

303.977 .1147

303.971 .7594

New Philadelphia Fan Co. (subsidiary of Howden) Johnston, Dave

330.339.1111 ext 233

Philadelphia Gear Corp.

Clifton, Bill

Pratt \& Whitney

Gissander, Joel

Cavina, Mike

Stewart \& Stevenson Services Inc.

Axford, Mark H.

NASA Ames Research Center

Kidwell, George

Bufton, Dan

Nguyen, Nhan

Ospring, Mike

Presley, Roy

Rolls-Royce (UK)

US Ait Force

Aker, Rick

Sverdrup Technology, Inc

Starr, Rogers

Jenke, Leroy

Johnson, Ward

Westinghouse

Rothos, Dan

Jones, Ken
610.265 .3000

ext 4553

860.565 .6546

404.714 .3432

713.868 .7700

713.868 .7650

415.604 .5060

415.604.4107

415.694.5876

415.604 .4077

415.604 .5851

44.133.266. 1461

210.925 .3687

615.455 .6400

615.393 .6694

615.393 .6311

615.393 .6674

407.281 .2000

407.281 .2140

801.566 .3600
Smyma, GA

Technical Engineer

Procurement Manager

P\&W engine for F22 Development

Recommended Dowty of U.K.

Dept. Manager, Wind Tunnels \& Aircraft Systems

Lead Project Engineer, Wind Tunnel \& Aircraft Systems

Denver, co

Experience with Kuznetsov rocket engines
King of Prussia, PA

East Hartford, CN

Engineer

Technical Engineer

Houston, $\mathrm{TX}$

Moffet Field, CA

Deputy Director of Aeronautics

Unitary Wind Tunnel

Facility Engineer

Engineering Manager

Aero Test \& Simulation Division

No Contact

San Antonio, TX

Engine Management office

No Contact

Tullahoma, TN

Vice President

Sales Engineer 
Appendix D

Characteristics of Candidate Systems 
Table D-1. Aircraft turbofan engine characteristics.

\begin{tabular}{|c|c|c|c|c|c|c|c|c|c|c|c|c|}
\hline & $\begin{array}{l}\text { Fan } \\
\text { Dia. }\end{array}$ & $\begin{array}{l}\text { Rated } \\
\text { Thrust } \\
\end{array}$ & $\begin{array}{l}\text { Fan Mass } \\
\text { Flow Rate }\end{array}$ & $\begin{array}{l}\text { Rated } \\
\text { Bypass } \\
\text { Ratio }\end{array}$ & $\begin{array}{c}\text { Fuel } \\
\text { Consump- } \\
\text { tion }\end{array}$ & $\begin{array}{c}\text { Average } \\
\text { Exhaust } \\
\text { Temp. }\end{array}$ & $\begin{array}{c}\text { Ex-core } \\
\text { Mass Flow } \\
\text { Rate }\end{array}$ & $\begin{array}{l}\text { Core mass } \\
\text { Flow Rate }\end{array}$ & $\begin{array}{c}\text { Average } \\
\text { Exit } \\
\text { Velocity }\end{array}$ & $\begin{array}{l}\text { Power } \\
\text { Output }\end{array}$ & Cost/ Status & \begin{tabular}{|c|} 
Approximate \\
Cost per MW of \\
Power
\end{tabular} \\
\hline & (m) & $(\mathbf{k N})$ & (kg/sec) & (BPR) & $(\operatorname{mgg} / \mathrm{Ns})$ & (K) & (kg/sec) & $(\mathrm{kg} / \mathrm{sec})$ & $(\mathrm{m} / \mathrm{sec})$ & (MW) & (\$ Millions) & $(\mathbf{S} / \mathbf{M W})$ \\
\hline & & & & & & & & & & & & \\
\hline$\frac{\text { USA GE90-76B }}{\text { USA GES0-85B }}$ & 3.12 & \begin{tabular}{l|l}
339.9 \\
\end{tabular} & $1,361.0$ & 8.65 & - & 600 & $1,220.0$ & 141.0 & 249.74 & 42.44 & $\$ 10-11 \mathrm{M}$ & 247,386 \\
\hline $\begin{array}{l}\text { USA GES0-85B } \\
\text { USA GES9-90B }\end{array}$ & 3.12 & 376.8 & $1,415.0$ & 8.65 & E & 600 & $1,268.4$ & 146.6 & 266.29 & 50.17 & $\$ 11-12 \mathrm{M}$ & 229,225 \\
\hline $\begin{array}{l}\text { USA GE90-90B } \\
\text { USA GE90-92B }\end{array}$ & $\begin{array}{l}3.12 \\
3.12 \\
\end{array}$ & 400.4 & $1,449.0$ & 8.65 & $E$ & 600 & $1,298.8$ & 150.2 & 276.33 & 55.32 & $\$ 12-13 \mathrm{M}$ & \begin{tabular}{r|}
225,954 \\
218,025
\end{tabular} \\
\hline & 3.12 & 409.3 & $1,461.0$ & 8.65 & & 600 & $1,309.6$ & 151.4 & 280.15 & 57.33 & $\$ 12-13 M$ & 218,025 \\
\hline $\begin{array}{l}\text { USA P\&W JT3D-1 } \\
\text { USA PSW T3-8B }\end{array}$ & 1.35 & 75.6 & 209.0 & 1.36 & 15.15 & 818 & 120.4 & 88.6 & 361.53 & 13.66 & Out of production & - \\
\hline USA P\&W JT3D-8B & 1.35 & 93.4 & 209.0 & 1.36 & 15.85 & 750 & 120.4 & 88.6 & 446.89 & 20.87 & Out of production & - \\
\hline USA P\&W & & & & & & & & & & & & \\
\hline \begin{tabular}{|l|} 
USA P\&W J19D-SA \\
USA P\&W JT9D-59A
\end{tabular} & $\frac{2.43}{2.46}$ & 200.8 & 684.0 & 5.17 & 17.67 & 725 & 573.1 & 110.9 & 293.57 & 29.47 & Out of production & - \\
\hline USA P\&W JT9D-7R4 & $\frac{2.46}{2.46}$ & 236.0 & 769.0 & 5.15 & 17.87 & 853. & 644.0 & 125.0 & $\frac{306.89}{37380}$ & $\frac{36.21}{40.311}$ & \begin{tabular}{|l|} 
Oat of production \\
Ont of production
\end{tabular} & - \\
\hline & & 249.01 & 769.0 & 5.01 & 17.42 & 848 & 641.0 & 128.0 & 323.80 & & & \\
\hline $\begin{array}{l}\text { USA P\&W } 2037 \\
\text { USA P\&W } 2040\end{array}$ & 1.99 & 170.1 & 608.0 & 6.00 & 9.35 & 733 & 521.1 & 86.9 & 279.77 & 23.79 & $\$ 6-7 \mathrm{M}$ & 252,160 \\
\hline \begin{tabular}{|l} 
USA P\&W 2040 \\
USA P\&W 2043
\end{tabular} & 1.99 & 181.9 & 608.0 & 6.00 & 9.35 & 750 & 521.1 & 86.9 & 299.18 & 27.21 & $57-8 \mathrm{M}$ & 257,256 \\
\hline USA P\&W 2043 & 1.99 & 191.2 & 608.0 & 6.00 & 9.35 & 750 & 521.1 & 86.9 & 314.47 & 30.06 & $\$ 88-9 M$ & 266,102 \\
\hline USA P\&W $\$ 052$ & & & & & & & & & & & & \\
\hline \begin{tabular}{|l|} 
USA P\&W 4052 \\
USA P\&W 4168 \\
\end{tabular} & 2.46 & 232.1 & 773.0 & 4.85 & 8.81 & 750 & 640.9 & 132.1 & 300.26 & 34.85 & $\$ 9-10 \mathrm{M}$ & 272,636 \\
\hline & 2.54 & 302.5 & 773.0 & 4.85 & 9.35 & 750 & 640.9 & 132.1 & 391.33 & 59.19 & $\$ 10-12 \mathrm{M}$ & 185,845 \\
\hline USA TF39-GE-1 & 2.44 & 182.8 & 700.0 & 8.00 & 8.93 & 750 & 622.2 & 77.8 & 261.14 & $23.87 \mathrm{~K}$ & Out of production & 1- \\
\hline USA TF $39-G E-1 C$ & 2.44 & 191.3 & 700.0 & 8.00 & 8.93 & 750 & 622.2 & 77.8 & 273.29 & 26.14 & Out of production & 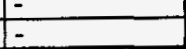 \\
\hline & & & & & & & & & & & & \\
\hline USA CFG-50A & 220 & 218.0 & 653.0 & 4.40 & 10.90 & 750 & 532.1 & 120.9 & 333.84 & 36.39 & Out of production & - \\
\hline USA CF6-50E & 2.20 & 233.5 & 673.0 & 4.40 & 10.65 & 750 & 548.4 & 124.6 & 346.95 & 40.51 & Out of production & E- \\
\hline & & & & & & & & & & & & \\
\hline $\begin{array}{l}\text { USA CF6-80C2A1 } \\
\text { USA CF6-80C2A5F }\end{array}$ & 2.69 & 257.4 & 802.0 & 5.03 & 9.46 & 750 & 669.0 & 133.0 & 320.95 & 41.31 & $\$ 12-13 \mathrm{M}$ & 302,620 \\
\hline USA CF6-80C2A5F & 2.69 & 267.3 & 805.0 & 5.06 & 9.63 & 750 & 672.2 & 132.8 & 332.05 & 44.38 & $\$ 12-13 \mathrm{M}$ & 281,668 \\
\hline GB Rolls-Trent 768 & & & & & & & & & & & & \\
\hline \begin{tabular}{|l} 
GB Rodills-1rent 768 \\
GB Rolls-Trent 772 \\
\end{tabular} & \begin{tabular}{r|}
2.47 \\
247
\end{tabular} & $\begin{array}{r}300.3 \\
316.3\end{array}$ & 876.0 & 5.75 & 16.00 & 750 & 746.2 & 129.8 & 342.81 & 51.47 & $\$ 11.12 \mathrm{M}$ & 223,420 \\
\hline GB Rolls-Treat 875 & $-\frac{2.47}{2.79}$ & \begin{tabular}{r|}
316.3 \\
346.5
\end{tabular} & 897.0 & 5.75 & 16.00 & 750 & 764.1 & 132.9 & 352.62 & 55.77 & $\$ 11-12 M$ & $\frac{206,216}{215,667}$ \\
\hline GB Rolls-Trent 877 & 2.79 & $\begin{array}{l}346.5 \\
356.2\end{array}$ & $1,126.0$ & 5.75 & 15.77 & 750 & 959.2 & 166.8 & 307.75 & $\frac{53.32}{54.28}$ & $\frac{\$ 11-12 M}{\$ 11-12 M}$ & $\frac{215,667}{211,876}$ \\
\hline GB Rolls-Trent 894 & 2.79 & $\frac{356.2}{384.8}$ & $1,169.0$ & 5.75 & 15.77| & 750 이 & $\begin{array}{r}995.8 \\
10282\end{array}$ & $\frac{173.2}{178.8}$ & $\frac{304.73}{318.81}$ & $\frac{54.28}{61.34}$ & $\frac{\$ 11-12 M}{\$ 12-13 M}$ & $\frac{211,876}{203,787}$ \\
\hline GB Rolls-Trent 890 & 2.79 & 384.8 & $\frac{1,207.0}{1,234.0}$ & $\begin{array}{l}5.75 \\
5.75\end{array}$ & $\begin{array}{l}15.77 \\
15.77\end{array}$ & $\begin{array}{l}750 \\
750\end{array}$ & $\begin{array}{l}1,028.2 \\
1,051.2\end{array}$ & 182.8 & 329.12 & 66.84 & $\$ 12-13 M$ & $\begin{array}{l}203,787 \\
187,027 \\
\end{array}$ \\
\hline & & & & & & & & & & & & \\
\hline Germiny BR710 & 1.22 & 65.8 & 197.0 & 3.00 & 17.81 & 750 & 147.8 & 49.3 & 334.16 & 11.00 & - & $1-$ \\
\hline & & & & & & & & & 772001 & & & \\
\hline \begin{tabular}{|l|} 
INT. CFM 56-2 \\
INT. CFM 56-3
\end{tabular} & 1.74 & 97.9 & 357.4 & 6.00 & 18.61 & 750 & 306.3 & 51.1 & 273.92 & \begin{tabular}{l|}
13.41 \\
17.62
\end{tabular} & $\$ 4-5 M$ & 298,318 \\
\hline \begin{tabular}{|l} 
INT. CFM 56-3 \\
INT. CFM 56-5
\end{tabular} & $\frac{1.52}{1.84}$ & $\frac{104.5}{151.3}$ & 309.8 & 5.00 & 18.55 & 750 & 258.2 & 51.6 & 337.31 & $\frac{17.62}{28.78}$ & $\$ 5-6 \mathrm{M}$ & $\frac{283,693}{308,458}$ \\
\hline INT. CFM 56-9(Lite) & 1.40 & $\begin{array}{l}117.4 \\
104.5 \\
\end{array}$ & $\begin{array}{l}329.3 \\
268.0\end{array}$ & $\frac{5.60}{5.17}$ & 16.98 & 750 & $\begin{array}{l}279.4 \\
224.6\end{array}$ & $\frac{49.9}{43.4}$ & $\frac{356.51}{389.93}$ & & $\$ 5-6 M$ & $\frac{238,922}{245,416}$ \\
\hline
\end{tabular}


Table D-2. Aircraft turboshaft engine characteristics.

\begin{tabular}{|c|c|c|c|c|c|c|c|c|c|c|}
\hline & $\begin{array}{c}\text { T-O } \\
\text { Power }\end{array}$ & $\begin{array}{c}\text { T-O } \\
\text { Power } \\
\end{array}$ & $\begin{array}{c}\text { Pressure } \\
\text { Ratio }\end{array}$ & $\begin{array}{c}\text { Mass } \\
\text { Flow Rate } \\
\end{array}$ & $\begin{array}{c}\text { Fuel } \\
\text { Consumption }\end{array}$ & Length & \begin{tabular}{|c|} 
Diameter of \\
Power \\
Section \\
\end{tabular} & $\begin{array}{c}\text { Dry } \\
\text { Weight }\end{array}$ & $\begin{array}{c}\text { Engine } \\
\text { Cost }\end{array}$ & $\begin{array}{l}\text { Specific } \\
\text { Cost }\end{array}$ \\
\hline & (MW) & (shp) & & $(\mathrm{kg} / \mathrm{sec})$ & $(\mathrm{lb} / \mathrm{h} / \mathrm{shp})$ & (in) & (in) & (lb) & $(\$ M)$ & $(\$ \mathrm{M}, \bar{W})$ \\
\hline Allison T56-A-425 & 3.42 & 4,591 & 9.6 & 14.7 & 0.501 & 146.3 & 27.0 & 1,899 & 0.8 & $\$ 233,645$ \\
\hline Allison T56-A-427 & 3.91 & 5,250 & 12.0 & 15.2 & 0.470 & 146.1 & 27.0 & 1,940 & 0.8 & $\$ 204,604$ \\
\hline Allison AE 2100A & 4.47 & 6,000 & - & - & 0.41 & - & 24.5 & 1,548 & 1.2 & $\$ 268,216$ \\
\hline Allison AE 2100C & 4.47 & 6,000 & - & - & 0.41 & - & 24.5 & 1,548 & 1.2 & $\$ 268,216$ \\
\hline Czech Walter M602 & 1.36 & 1,824 & 4.2 & 7.3 & 0.559 & 105.1 & 29.7 & 570 & $\overline{-}$ & $\because$ \\
\hline Dvigatel NK-93 (propfan) & 22.40 & 30,000 & 37.0 & 1000 & 0.490 & 216.5 & 124.0 & 8,047 & - & 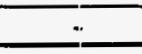 \\
\hline France Turbomeca Astazou & 0.93 & 877 & - & - & 0.525 & 80.6 & 21.5 & 454 & - & $\therefore$ \\
\hline Knmmetsov NK-12 & 8.95 & 11,995 & 13.0 & 62 & 0.501 & 188.4 & 46.9 & 6,393 & 0.9 & $\$ 100,615$ \\
\hline Kumnetsov NK-12M & 11.18 & 14,995 & 13.0 & 65 & 0.501 & 188.4 & 46.9 & 6,393 & 0.9 & $\$ 80,486$ \\
\hline Kurnetsov NK-12MV & 11.03 & 14,795 & 13.0 & 65 & 0.501 & 185.8 & 46.9 & 5,710 & 0.9 & $\$ 81,573$ \\
\hline Kuzaetsov NK-12MA & 11.19 & 15,000 & 13.0 & 65 & 0.501 & 197.0 & 46.9 & 5,710 & 0.9 & $\$ 80,458$ \\
\hline Poland TWD-10B & 0.75 & 1,000 & 7.4 & 4.6 & 0.570 & 81.1 & 21.9 & 661 & - & - \\
\hline P\&WC PT6A-6 & 0.43 & 578 & 6.7 & 3.1 & 0.200 & 62.0 & 19.0 & 270 & - & - \\
\hline P\&WC PT6A-27 & 0.55 & 715 & 6.7 & 3.1 & 0.200 & 62.0 & 19.0 & 335 & - & $\therefore$ \\
\hline P\&WC PT6A-65 & 0.88 & 1174 & 10.0 & 4.3 & 0.200 & 74.0 & 19.0 & 481 & - & $=$ \\
\hline Russia TV7-117 & 1.84 & 2,467 & 16.0 & 8.0 & 0.397 & 84.4 & 34.9 & 1,146 & - & - \\
\hline Russia TVD-20 & 1.04 & 1,400 & 9.0 & 5.4 & 0.506 & 69.7 & 33.5 & 628 & - & $=$ \\
\hline US GE CT7-6 & 1.49 & 2,000 & - & - & 0.476 & 79.0 & 26.0 & 720 & - & - \\
\hline US GE T64 & 3.27 & 4,380 & 13.4 & - & 0.477 & 79.0 & 26.0 & 720 & $=$ & - \\
\hline Ukraine AI-20D & 3.86 & 5,180 & 9.2 & 20.7 & 0.529 & 121.9 & 33.2 & 2,293 & - & - \\
\hline Ukraine AI-24 & 1.88 & 2,515 & 7.6 & 13.1 & 0.54 & 92.4 & 26.7 & 1,323 & - & - \\
\hline Ukraine D-236 (propfan) & 8.09 & \begin{tabular}{|l|}
10,850 \\
\end{tabular} & - & $=$ & 0.359 & - & - & - & - & - \\
\hline Ukraine D-27 (propfan) & 10.29 & 13,800 & $=$ & - & 0.57 & 212.6 & 109.9 & 9,039 & $=$ & - \\
\hline UK Rolls-Royce Dart & 2.24 & 3,000 & 5.4 & 9.75 & 0.578 & 98.4 & 37.9 & 1,268 & - & - \\
\hline UK Rolls-Royce Tynet & 4.92 & 6,600 & 14.0 & 21.1 & 0.485 & 108.7 & 55.0 & 2,177 & - & - \\
\hline
\end{tabular}


Table D-3. Gas turbine engine prices from Gas Turbine Engineering, Inc. (http://www.gas-turbines.com) as of July 6, 1996.

\begin{tabular}{|c|c|c|c|c|c|c|}
\hline Manufacturer & Model & Rpm & $\begin{array}{l}\text { Output } \\
\text { (kW) }\end{array}$ & $\begin{array}{l}\text { Heat } \\
\text { Rate }\end{array}$ & $\begin{array}{l}\text { Cost } \\
\text { (\$M) }\end{array}$ & $\$ / K W$ \\
\hline $\mathrm{ABB}$ & GT35 & 3600 & 16,360 & 10,600 & 8 & $\$ 489.00$ \\
\hline ABB & GT10 & 7700 & 21,800 & 10,405 & 9.5 & $\$ 435.78$ \\
\hline ABB & GT10 & 7700 & 24,630 & 9,965 & 10.1 & $\$ 410.07$ \\
\hline ABB & GT8 & 6300 & 48,500 & 10,750 & 15.6 & $\$ 321.65$ \\
\hline ABB & GT8C & 6200 & 52,600 & 9,980 & 16 & $\$ 304.18$ \\
\hline$A B B$ & GT11N & 3600 & 81,600 & 10,700 & 20.5 & $\$ 251.23$ \\
\hline ABB & GT11N & 3600 & 83,880 & 10,370 & 20.5 & $\$ 244.40$ \\
\hline$A B B$ & GT11N2 & 3600 & 109,200 & 10,030 & 24.5 & $\$ 224.36$ \\
\hline ABB & GT13D2 & 3000 & 100,500 & 10,600 & 22.5 & $\$ 223.88$ \\
\hline $\mathrm{ABB}$ & GT13E & 3000 & 148,000 & 9,855 & 31 & $\$ 209.46$ \\
\hline ABB & GT13E2 & 3000 & 164,300 & 9,560 & 36 & $\$ 219.11$ \\
\hline ALLISON & $501 \mathrm{~KB} 5$ & 14250 & 3,725 & 12,317 & 1.8 & $\$ 483.22$ \\
\hline ALLISON & $501 \mathrm{KH}$ & 14600 & 3,740 & 12,363 & 2.1 & $\$ 561.50$ \\
\hline ALLISON & 570KA & 11500 & 4,610 & 12,225 & 2.6 & $\$ 563.99$ \\
\hline ALLISON & $571 \mathrm{KA}$ & 11500 & 5,590 & 10,650 & 2.8 & $\$ 500.89$ \\
\hline DRESSER & DC990 & 7200 & 4,200 & 11,820 & 2 & $\$ 476.19$ \\
\hline GE & 5271RA & 5100 & 20,260 & 12,800 & 5.7 & $\$ 281.34$ \\
\hline GE & 5371PA & 5100 & 26,785 & 11,730 & 7.5 & $\$ 280.01$ \\
\hline GE & M5382C & 4670 & 28,337 & 11,667 & 7.7 & $\$ 271.73$ \\
\hline GE & $6541 B$ & 5100 & 39,325 & 10,560 & 10.5 & $\$ 267.01$ \\
\hline GE & 6101FA & 5100 & 71,750 & 9,740 & 18.5 & $\$ 257.84$ \\
\hline GE & 7111EA & 3600 & 84,920 & 10,212 & 19.3 & $\$ 227.27$ \\
\hline GE & 7171EF & 3600 & 126,200 & 9,990 & 28.8 & $\$ 228.21$ \\
\hline GE & $7191 F$ & 3600 & 151,300 & 9,625 & 30.4 & $\$ 200.93$ \\
\hline GE & 7221FA & 3600 & 161,650 & 9,243 & 34 & $\$ 210.33$ \\
\hline GE & 9161E & 3000 & 119,355 & 10,105 & 23.8 & $\$ 199.41$ \\
\hline GE & 9171E & 3000 & 125,940 & 9,890 & 24.5 & $\$ 194.54$ \\
\hline GE & 9231EC & 3000 & 173,680 & 9,435 & 32.2 & $\$ 185.40$ \\
\hline GE & $9281 \mathrm{~F}$ & 3000 & 217,870 & 9,625 & 39.9 & $\$ 183.14$ \\
\hline GE & $9301 \mathrm{~F}$ & 3000 & 214,000 & 9,700 & 42 & $\$ 196.26$ \\
\hline GE & 9311FA & 3000 & 228,195 & 9,360 & 45 & $\$ 197.20$ \\
\hline GE & LM500 & 7000 & 3,880 & 11,430 & 1.9 & $\$ 489.69$ \\
\hline GE & LM1600 & 7000 & 13,430 & 9,560 & 6.9 & $\$ 513.78$ \\
\hline GE & LM2500 & 3600 & 22,216 & 9,404 & 9.5 & $\$ 427.62$ \\
\hline GE & LM2500PH & 3600 & 19,700 & 9,630 & 10.3 & $\$ 522.84$ \\
\hline GE & LM5000PD & 3600 & 33,350 & 9,390 & 13.6 & $\$ 407.80$ \\
\hline GE & LM5-ST80 & 3600 & 46,300 & 8,170 & 14.7 & $\$ 317.49$ \\
\hline GE & LM5-ST120 & 3600 & 51,500 & 7,885 & 15.3 & $\$ 297.09$ \\
\hline GE & LM5000PC & 3600 & 33,700 & 9,350 & 13.8 & $\$ 409.50$ \\
\hline GE & LM6000PA & 3600 & 41,020 & 8,720 & 12.1 & $\$ 294.98$ \\
\hline GE & LM6 50HZ & 3600 & 40,410 & 8,850 & 12.6 & $\$ 311.80$ \\
\hline KWU & V64.3 & 5400 & 60,650 & 9,705 & 18.5 & $\$ 305.03$ \\
\hline KWU & V84.2 & 3600 & 103,200 & 10,220 & 23.5 & $\$ 227.71$ \\
\hline KWU & V84.2 & 3600 & 106,200 & 10,124 & 23.3 & $\$ 219.40$ \\
\hline KWU & V84.3 & 3600 & 139,000 & 9,560 & 33 & $\$ 237.41$ \\
\hline KWU & V84.3 & 3600 & 152,700 & 9,450 & 34.5 & $\$ 225.93$ \\
\hline KWU & V94.2 & 3000 & 148,800 & 10,210 & 30.2 & $\$ 202.96$ \\
\hline KWU & V94.2 & 3000 & 154,000 & 10,065 & 30.2 & $\$ 196.10$ \\
\hline KWU & V94.3 & 3000 & 200,360 & 9,550 & 41 & $\$ 204.63$ \\
\hline
\end{tabular}


Table D-3. (continued).

$\begin{array}{llrrrrr}\text { KWU } & \text { V94.3 } & 3000 & 219,000 & 9,450 & 45 & \$ 205.48 \\ \text { MITSUBISHI } & \text { MF111A } & 9660 & 12,835 & 11,175 & 5.8 & \$ 451.89 \\ \text { MITSUBISHI } & \text { MF111B } & 9660 & 14,845 & 10,895 & 6.2 & \$ 417.65 \\ \text { MITSUI } & \text { SB60 } & 5680 & 12,650 & 11,460 & 5.9 & \$ 466.40 \\ \text { NUOVO PIGNONE } & \text { PGT10 } & 7900 & 9,980 & 10,500 & 5.2 & \$ 521.04 \\ \text { RR } & \text { SPEY SK15 } & 5220 & 11,630 & 10,510 & 5.7 & \$ 490.11 \\ \text { RR } & \text { AVON } & 5500 & 14,610 & 11,885 & 4.8 & \$ 328.54 \\ \text { RR } & \text { RB211 } & 4800 & 25,250 & 9,550 & 11.1 & \$ 439.60 \\ \text { RR } & \text { RB211 } & 4800 & 27,240 & 9,575 & 11.5 & \$ 422.17 \\ \text { RUSTON } & \text { TB5000 } & 7950 & 3,830 & 13,450 & 1.7 & \$ 443.86 \\ \text { RUSTON } & \text { TORNADO } & 11085 & 6,215 & 11,340 & 2.9 & \$ 466.61 \\ \text { RUSTON } & \text { TYPHOON } & 16570 & 3,945 & 11,360 & 2 & \$ 506.97 \\ \text { RUSTON } & \text { TYPHOON } & 17380 & 4,550 & 11,350 & 2.1 & \$ 461.54 \\ \text { RUSTON } & \text { HURRICANE } & 27245 & 1,575 & 13,820 & 1.1 & \$ 698.41 \\ \text { SOLAR } & \text { SATURN } & 22120 & 1,080 & 14,685 & 0.8 & \$ 740.74 \\ \text { SOLAR } & \text { CENTAUR } & 14950 & 3,880 & 12,250 & 1.7 & \$ 438.14 \\ \text { SOLAR } & \text { TAURUS } & 14950 & 4,370 & 12,250 & 1.9 & \$ 434.78 \\ \text { SOLAR } & \text { MARS } & 8568 & 8,840 & 10,975 & 4.3 & \$ 486.43 \\ \text { SOLAR } & \text { MARS } & 9000 & 10,000 & 10,550 & 4.6 & \$ 460.00 \\ \text { TURBOMECA } & \text { M } & 22000 & 1,086 & 13,125 & 0.9 & \$ 828.73 \\ \text { TP\&M } & \text { FT4C-3F } & 3600 & 29,810 & 10,875 & 5.7 & \$ 191.21 \\ \text { TP\&M } & \text { FT8 } & 3600 & 25,600 & 8,875 & 11 & \$ 429.69 \\ \text { WESTINGHOUSE } & \text { 251 B10A } & 5420 & 42,300 & 10,600 & 11 & \$ 260.05 \\ \text { WESTINGHOUSE } & \text { 251 B12 } & 5400 & 47,660 & 10,420 & 13 & \$ 272.77 \\ \text { WESTINGHOUSE } & 251 \text { B12A } & 5400 & 49,200 & 10,440 & 14 & \$ 284.55 \\ \text { WESTINGHOUSE } & \text { 501 D5 } & 3600 & 106,800 & 10,100 & 22.1 & \$ 206.93 \\ \text { WESTINGHOUSE } & \text { 501 D5 } & 3600 & 109,350 & 10,010 & 23 & \$ 210.33 \\ \text { WESTINGHOUSE } & \text { 501 D5 } & 3600 & 121,300 & 9,890 & 25 & \$ 206.10 \\ \text { WESTINGHOUSE } & \text { 501F } & 3600 & 163,530 & 9,470 & 34.5 & \$ 210.97 \\ \text { WESTINGHOUSE } & 701 D 5 & 3000 & 133,750 & 9,960 & 26.5 & \$ 198.13 \\ \text { WESTINGHOUSE } & 701 D A & 3000 & 138,520 & 10,040 & 27.5 & \$ 198.53 \\ \text { WESTINGHOUSE } & \text { 701F } & 3000 & 235,720 & 9,280 & 47 & \$ 199.39\end{array}$


Table D-4. Gas turbine engines listed by supplier.

\begin{tabular}{|c|c|c|c|}
\hline MANUFACTURER & MODEL & $\begin{array}{l}\text { OUTPUT } \\
\text { MW }\end{array}$ & $\begin{array}{l}\text { HEAT RATE } \\
\text { BTU / KW }\end{array}$ \\
\hline Allied Signal Engines & AS 4055 & 4 & 8960 \\
\hline Allison Engine Company & 501-KH (STEAM INJ & 6.75 & 8560 \\
\hline Allison Engine Company & $571-K$ & 5.91 & 10074 \\
\hline Allison Engine Company & $501-K B 7$ & 5.22 & 10826 \\
\hline Allison Engine Company & 501-KB5S & 4.1 & 11570 \\
\hline Allison Engine Company & 501-KB4 (STANDBY & 4.33 & 11697 \\
\hline Allison Engine Company & $501-K B 3$ & 2.84 & 13136 \\
\hline Ansaldo Energia & V84.3 & 154 & 9426 \\
\hline Ansaldo Energia & V94.3 & 222 & 9426 \\
\hline Ansaldo Energia & V64.3 & 63 & 9640 \\
\hline Ansaldo Energia & V94.2 & 159 & 9977 \\
\hline Ansaldo Energia & V84.2 & 109 & 10126 \\
\hline Centrax Gas Turbine & CX501-KH & 6 & 9115 \\
\hline Centrax Gas Turbine & CX501-KN7 & 5.6 & 10992 \\
\hline Centrax Gas Turbine & CX571 & 5.4 & 11260 \\
\hline Centrax Gas Turbine & CX501-KN5 & 4.5 & 11394 \\
\hline Centrax Gas Turbine & $\mathrm{C} \times 501-\mathrm{KB} 7$ & 5 & 11662 \\
\hline Centrax Gas Turbine & CX501-KB5 & 3.8 & 12332 \\
\hline Centrax Gas Turbine & CX501-KN3 & 3.1 & 12601 \\
\hline Centrax Gas Turbine & CX501-KB3 & 2.7 & 13673 \\
\hline Cooper Rolls, Inc. & Coberra 6000 & 27.21 & 9534 \\
\hline Cooper Rolls, Inc. & Coberra 2000 & 14.58 & 12097 \\
\hline Dresser Rand & DR63G & 41.95 & 8425 \\
\hline Dresser Rand & DR61 PLUS & 28.5 & 8916 \\
\hline Dresser Rand & DH61G & 23.28 & 9084 \\
\hline Dresser Rand & DR61 & 22.98 & 9115 \\
\hline Dresser Rand & DR61G PLUS & 27.6 & 9141 \\
\hline Dresser Rand & DR60G & 14.07 & 9169 \\
\hline Dresser Rand & DR990 & 4.4 & 11193 \\
\hline Dresser-Rand & DA-63G & 40.67 & 8694 \\
\hline Dresser-Rand & DR-61 PLUS & 27.63 & 9130 \\
\hline Dresser-Rand & DR-61G & 22.8 & 9273 \\
\hline Dresser-Rand & DR-61G PLUS & 27.04 & 9330 \\
\hline Dresser-Rand & DR-61 & 22.06 & 9450 \\
\hline Dresser-Rand & DR-60G & 13.58 & 9505 \\
\hline Dresser-Rand & KG2-3E (STANDBY) & 2.14 & 20249 \\
\hline Dresser-Rand & KG2-3E & 1.85 & 20652 \\
\hline Dresser-Rand & KG2-3C (STANDBY) & 1.8 & 21278 \\
\hline Dresser-Rand & $\mathrm{KG} 2-3 \mathrm{C}$ & 1.45 & 21620 \\
\hline
\end{tabular}


Table D-4. (continued).

\begin{tabular}{|c|c|c|c|}
\hline Ebara & PW7M & 0.78 & 14538 \\
\hline Ebara & PW14M & 1.56 & 14538 \\
\hline Ebara & PW6M & 0.64 & 15168 \\
\hline Ebara & PW12M & 1.28 & 15168 \\
\hline Ebara Corporation & FT 8 T win & 51.1 & 8905 \\
\hline Ebara Corporation & FT 8 & 25.42 & 8950 \\
\hline Ebara Corporation & PW 7E & 0.7 & 15535 \\
\hline Ebara Corporation & PW 6E & 0.57 & 16300 \\
\hline European Gas Turbines & RLM6000 & 40.6 & 8632 \\
\hline European Gas Turbines & RLM5000 & 35.05 & 9019 \\
\hline European Gas Turbines & RLM2500 & 23.3 & 9080 \\
\hline European Gas Turbines & RLM2500+ & 27.6 & 9139 \\
\hline European Gas Turines & RLM1600 & 13.98 & 9189 \\
\hline European Gas Turines & RLM2500-PE & 22.8 & 9270 \\
\hline European Gas Turbines & RLM5000-PC & 34.3 & 9270 \\
\hline European Gas Turbines & RLM2500+ & 27 & 9335 \\
\hline European Gas Turines & RLM5000-PC & 34.3 & 9355 \\
\hline European Gas Turbines & M5352 & 26.56 & 9370 \\
\hline European Gas Turbines & M5322R & 23.87 & 9477 \\
\hline European Gas Turbines & PG 9331 FA & 226.5 & 9570 \\
\hline European Gas Turbines & RLM2500-PE & 21.9 & 9597 \\
\hline European Gas Turbines & RLM1600 & 13.4 & 9633 \\
\hline European Gas Turbines & M3142R & 10.44 & 9933 \\
\hline European Gas Turbines & PG $9171 \mathrm{E}$ & 123.4 & 10100 \\
\hline European Gas Turbines & G3142R(J) & 10 & 10370 \\
\hline European Gas Turbines & TORNADO & 6.64 & 10760 \\
\hline European Gas Turbines & PG $6541 \mathrm{~B}$ & 38.3 & 10860 \\
\hline European Gas Turbines & Typhoon & 4.9 & 11145 \\
\hline European Gas Turbines & Tornado & 6.2 & 11265 \\
\hline European Gas Turbines & Typhoon & 4.2 & 11405 \\
\hline European Gas Turbines & M5382 & 28.35 & 11662 \\
\hline European Gas Turbines & PG 5371 PA & 26.3 & 11990 \\
\hline European Gas Turines & TB5000 & 4.03 & 12586 \\
\hline European Gas Turbines & M3142 & 10.89 & 12775 \\
\hline European Gas Turbines & TB5000 & 3.8 & 13240 \\
\hline European Gas Turbines & G3142(J) & 10.4 & 13320 \\
\hline European Gas Turbines & Hurricane & 1.6 & 13920 \\
\hline Fiat Avio Power Division & LM6000 $(60 \mathrm{~Hz})$ & 41.09 & 8607 \\
\hline Fiat Avio Power Division & LM6000 $(50 \mathrm{~Hz})$ & 40.48 & 8738 \\
\hline Fiat Avio Power Division & LM2500 $(60 \mathrm{~Hz})$ & 22.82 & 9273 \\
\hline Fiat Avio Power Division & $701 \mathrm{~F}$ & 233.95 & 9290 \\
\hline Fiat Avio Power Division & LM2500 $(50 \mathrm{~Hz})$ & 21.87 & 9600 \\
\hline Fiat Avio Power Division & TG50D5S & 147.75 & 9880 \\
\hline Fiat Avio Power Division & TG50D5 & 140.77 & 9890 \\
\hline Fiat Avio Power Division & TG20B11/12 & 47.8 & 10200 \\
\hline ivisio & TG2 & 36 & 1 \\
\hline
\end{tabular}


Table D-4. (continued).

\begin{tabular}{|c|c|c|c|}
\hline FIAT TTG & TG7 & 8.6 & 14110 \\
\hline FIAT TTG & TG16 & 18.4 & 12720 \\
\hline FIAT TTG & TG20 & 38.43 & 11130 \\
\hline FIAT TTG & TG50 & 92.65 & 10930 \\
\hline Greenwich Turbine, Inc. & FT4A-9 & 19.8 & 12150 \\
\hline Greenwich Turbine, Inc. & FT4C-3F & 28.1 & 11100 \\
\hline Greenwich Turbine, Inc. & LM2500 & 22.8 & 9273 \\
\hline Greenwich Turbine, Inc. & LM6000 & 39.9 & 8790 \\
\hline Greenwich Turbine, Inc. & PG6541B & 38.3 & 10880 \\
\hline John Brown Engineering & PG5371 & 26.3 & 11990 \\
\hline John Brown Engineering & PG6541 & 38.34 & 10880 \\
\hline John Brown Engineering & PG6101 & 70.14 & 9980 \\
\hline John Brown Engineering & PG7111 & 83.5 & 10480 \\
\hline John Brown Engineering & PG7231 & 167.8 & 9420 \\
\hline John Brown Engineering & PG9171 & 123.4 & 10110 \\
\hline John Brown Engineering & PG9331 & 226.5 & 9570 \\
\hline John Brown Engineering & LM6000 & 39.97 & 8790 \\
\hline KAWASAKI H.I. LTD. & S1A-02 & 0.21 & 20740 \\
\hline KAWASAKI H.I. LTD. & S1T-02 & 0.42 & 21100 \\
\hline KAWASAKI H.I. LTD. & S2A-01 & 0.7 & 15610 \\
\hline KAWASAKI H.I. LTD. & M1A-01 & 1.17 & 16310 \\
\hline KAWASAKI H.I. LTD. & M1A-03 & 1.47 & 15610 \\
\hline KAWASAKI H.I. LTD. & M1T-01 & 2.26 & 16710 \\
\hline KAWASAKI H.I. LTD. & M1T-03 & 2.82 & 15970 \\
\hline KAWASAKI H.I. LTD. & M1A-11 & 1.3 & 13900 \\
\hline KAWASAKI H.I. LTD. & M1A-13 & 1.55 & 13400 \\
\hline KAWASAKI H.I. LTD. & M1A-23 & 2.15 & 13000 \\
\hline KAWASAKI H.I. LTD. & M1T-13 & 3.06 & 13590 \\
\hline KAWASAKI H.I. LTD. & M1T-23 & 4.19 & 13140 \\
\hline KAWASAKI H.I. LTD. & M1A-13CC & 1.37 & 15330 \\
\hline KAWASAKI H.I. LTD. & M1A-13CC STM. IN. & 2.42 & 10140 \\
\hline KAWASAKI H.I. LTD. & M7A-01 & 5.96 & 11200 \\
\hline \multicolumn{2}{|c|}{ KVAERNER ENERGY ASLM1600 PA } & 13.4 & 9565 \\
\hline \multicolumn{2}{|c|}{ KVAERNER ENERGY ASLM2500 PE } & 22.2 & 9404 \\
\hline \multicolumn{2}{|c|}{ KVAERNER ENERGY AS LM6000 PA } & 39.56 & 8593 \\
\hline \multicolumn{2}{|c|}{ KVAERNER ENERGY ASPG5371 PA } & 26.3 & 11990 \\
\hline \multicolumn{2}{|c|}{ KVAERNER ENERGY ASPG6541 B } & 38.34 & 10880 \\
\hline \multicolumn{2}{|c|}{ KVAERNER ENERGY ASPG6101 FA } & 70.14 & 9980 \\
\hline \multicolumn{2}{|c|}{ KVAERNER ENERGY ASPG7111 EA } & 83.5 & 10480 \\
\hline \multicolumn{2}{|c|}{ KVAERNER ENERGY ASPG7221 FA } & 159 & 9500 \\
\hline \multirow{2}{*}{\multicolumn{2}{|c|}{$\begin{array}{l}\text { KVAERNER ENERGY ASPG9171 E } \\
\text { KVAERNER ENERGY ASPG9331 FA }\end{array}$}} & 123.4 & 10100 \\
\hline & & 226.5 & 95 \\
\hline
\end{tabular}


Table D-4, (continued).

\begin{tabular}{|c|c|c|c|}
\hline MITSUBISHI H.I. LTD. & MF-61 & 5.92 & 11915 \\
\hline MITSUBISHI H.I. LTD. & $M F-111 A$ & 12.61 & 11250 \\
\hline MITSUBISHI H.I. LTD. & MF-111B & 14.57 & 11020 \\
\hline MITSUBISHI H.I. LTD. & MF-221 & 30 & 10655 \\
\hline MITSUBISHI H.I. LTD. & MW-251 & 36.8 & 11790 \\
\hline MITSUBISHI H.I. LTD. & MW-501 & 104.5 & 10255 \\
\hline MITSUBISHI H.I. LTD. & $M W-701$ & 130.5 & 10070 \\
\hline MITSUBISHI H.I. LTD. & MW-701DA & 136.9 & 10040 \\
\hline MITSUBISHI H.I. LTD. & $501 \mathrm{~F}$ & 158.6 & 9475 \\
\hline MITSUBISHI H.I. LTD. & $701 \mathrm{~F}$ & 234.2 & 9330 \\
\hline MITSUBISHI H.I. LTD. & $501 \mathrm{G}$ & 230 & 8859 \\
\hline MITSUBISHI H.I. LTD. & MFT-8 & 26.78 & 8825 \\
\hline MITSUI ENG.\& S.B.CO. & SB5 & 1.08 & 13390 \\
\hline MITSUI ENG.\& S.B.CO. & SB15 & 2.72 & 13330 \\
\hline MITSUI ENG.\& S.B.CO. & SB30 & 5.41 & 13140 \\
\hline MITSUI ENG.\& S.B.CO. & SB60 & 12.49 & 11530 \\
\hline MITSUI ENG.\& S.B.CO. & SB60 & 13.57 & 11490 \\
\hline MITSUI ENG.\& S.B.CO. & SB120 & 23 & 11190 \\
\hline Nuovo Pignone & PGT 2 & 2 & 13642 \\
\hline Nuovo Pignone & PGT 5 & 5.22 & 12676 \\
\hline Nuovo Pignone & PGT 10 & 10.14 & 11046 \\
\hline Nuovo Pignone & PGT 16 & 13.39 & 9692 \\
\hline Nuovo Pignone & PGT 25 & 21.91 & 9621 \\
\hline Nuovo Pignone & LM2500 & 22.33 & 9445 \\
\hline Nuovo Pignone & MS5001 & 26.3 & 11984 \\
\hline Nuovo Pignone & MS6001 & 38.34 & 10858 \\
\hline Nuovo Pignone & LM6000 & 40 & 8764 \\
\hline Nuovo Pignone & MS6001FA & 70.14 & 9976 \\
\hline Nuovo Pignone & MS7001E & 83.5 & 10469 \\
\hline Nuovo Pignone & MS9001E & 123.4 & 10090 \\
\hline Nuovo Pignone & MS9001EC & 169.2 & 9759 \\
\hline Nuovo Pignone & MS9001FA & 226.5 & 9559 \\
\hline \multicolumn{2}{|c|}{ Parsons Power Generatio RB211 } & 27.21 & 9534 \\
\hline \multicolumn{2}{|c|}{ Parsons Power Generatio TRENT } & 51.19 & 8210 \\
\hline \multicolumn{2}{|c|}{ Parsons Power Generatio 251B11 } & 49.2 & 10440 \\
\hline \multicolumn{2}{|c|}{$\begin{array}{l}\text { Parsons Power Generatio 701DA } \\
\text { Parsons Power Generatio 701F }\end{array}$} & 138.3 & 9990 \\
\hline \multicolumn{2}{|c|}{ Parsons Power Generatio 701F } & 236.7 & 9280 \\
\hline Solar & Mars $100 \& 100$ s & 10.69 & 10505 \\
\hline Solar & Mars $90 \& 90 \mathrm{~s}$ & 9.29 & 10765 \\
\hline Solar & Taurus $70 \& 70 \mathrm{~s}$ & 6.3 & 10900 \\
\hline Solar & Taurus $60 \& 60 \mathrm{~s}$ & 5 & 11250 \\
\hline Solar & Centaur $50 \& 50 s$ & 4.35 & 11865 \\
\hline Solar & Centaur $40 \& 40$ s & 3.52 & 12240 \\
\hline Solar & Saturn 20 & 1.14 & 14075 \\
\hline
\end{tabular}


Table D-4. (continued).

Stewart and Stevenson

Stewart and Stevenson

Stewart and Stevenson

Stewart and Stevenson

Stewart and Stevenson

Stewart and Stevenson

Stewart and Stevenson

Stewart and Stevenson

Stewart and Stevenson

Stewart and Stevenson

Stewart and Stevenson

Stewart and Stevenson

Thomassen International G3142

Thomassen International G3142R

Thomassen International PG5271

Thomassen International PG5371

Thomassen International PG6541

Thomassen International PG9171

Thomassen International PG9331

Thomassen International PG6101

Thomassen International PG9231

Tuma Turbomach

Tuma Turbomach

Tuma Turbomach

Tuma Turbomach

Tuma Turbomach

Tuma Turbomach

Tuma Turbomach
TGC105CS

TGC308CC

TGC378CH

TGC435CT

TGC880CM

TGC100CM

TGC111MF

$\begin{array}{rr}51.62 & 7790 \\ 48.1 & 8070 \\ 28.05 & 8325 \\ 40.76 & 8590 \\ 16.5 & 8641 \\ 34.4 & 9180 \\ 22.8 & 9280 \\ 27.05 & 9330 \\ 13.44 & 9545 \\ 7.5 & 10876 \\ 4.91 & 11142 \\ 6.25 & 11265\end{array}$

10.45

13337

10378

12835

12000

10871

10112

9581

9960

9790

168.9

$1.1 \quad 14102$

$3.5 \quad 12233$

$4.1 \quad 12170$

$4.8 \quad 11271$

$9.3 \quad 10741$

$10.7 \quad 10534$

$14.3 \quad 10351$ 
Appendix E

Kuznetsov NK12-MV Properties 


\section{Appendix E}

\section{Kuznetsov NK12-MV Properties}

Table E-1. General dimensions.

$\begin{array}{lll}\text { Mass } & \text { (engine) } & <3,300 \mathrm{~kg} \\ \text { Mass } & \text { (engine + packing crate) } & 5,500 \mathrm{~kg} \\ \text { Length } & \text { engine } & 4.72 \mathrm{~m} \\ \text { Diameter } & \text { engine } & 1.20 \mathrm{~m} \\ \text { Diameter } & \text { Engine mount points } & 1.37 \mathrm{~m} \\ \text { Diameter } & \text { Propeller AB-60K } & 5.3 \mathrm{~m}\end{array}$

Table E-2. Reliability information for ground-based operation with AB-60k propeller.

Mean time between failure (with gearbox \&

propellers in ground application)

Time between overhaul (gearbox only)

Time between overhaul (engine)

Mean time to repair

Mean recovery time

Probablility of failure free operation per

1,000 hours
23,500 hours

4000 hours

12 years $^{\mathrm{a}}$

10,000 hours

5 hours

0.819

a. Vendor language

Table E-3. Particle ingestion limits for normal service life.

Atmospheric Dust Content Limits for Normal Service Life
Average dust content
$0.3 \mathrm{mg} / \mathrm{m} 3$
Diameter $>20 \mathrm{~mm}$
$0.03 \mathrm{mg} / \mathrm{m} 3$

Short Term Conditions (not to exceed 5\% of Service Life)

Dust content

$5 \mathrm{mg} / \mathrm{m} 3$

Maximum particle size

$30 \mathrm{~mm}$

Ingress of foreign objects is not allowed 
Table E-4. Combustion products at standard atmospheric conditions.

\begin{tabular}{lr} 
Combustion Product & Level $(\mathrm{mg} / \mathrm{m} 3)$ \\
\hline Nox & 142 \\
CO & 114 \\
CxHy & 132 \\
Benzopyrene & 0,000021
\end{tabular}

Table E-5. Sound pressures for NK12-MV on indoor test stand.

\begin{tabular}{|c|c|c|}
\hline Source & Level $(\mathrm{dB})$ & Range $(\mathrm{kHz})$ \\
\hline$\overline{\text { Engine Inlet }}$ & 140 & $1-10$ \\
\hline Engine Outlet & 143 & $1-10$ \\
\hline Engine Casing Vibration (near air intake) & 113 & $0.8-16$ \\
\hline Engine Casing Vibration (near exhaust nozzle) & 120 & $0.8-16$ \\
\hline
\end{tabular}

Note: Sound pressure level drops $2-5 \%$ in outdoor environment

Table E-6. NK12-MV engine operation parameters.

Engine Core Air Flow

Maximum

$56 \mathrm{~kg} / \mathrm{s}$

Maximum Continuous

$56 \mathrm{~kg} / \mathrm{s}$

Propeller Air Flow (no power given)

AB-60K (5.3 m)

$\mathrm{AB}-90 \quad(6.2 \mathrm{~m})^{\mathrm{a}}$

$930 \mathrm{~kg} / \mathrm{sec}$

$1,950 \mathrm{~kg} / \mathrm{sec}$

Fuel Consumption

Maximum

$0.847 \mathrm{~kg} / \mathrm{s}$

Maximum Continuous

Exhaust Gas Temperature

Start-up (up to $15 \mathrm{sec}$ )

$0.740 \mathrm{~kg} / \mathrm{s}$

Maximum Power at $25 \mathrm{C}$ ambient

$600 \mathrm{C}$

Maximum Power at $60 \mathrm{C}$ ambient

$550 \mathrm{C}$

$580 \mathrm{C}$

Starting \& Control System

Voltage

Engine Start Current $(4-8 \mathrm{sec})$

$24-27 \mathrm{VDC}$

Engine Start Current ( $2 \mathrm{~min}$ )

$<3 \mathrm{~kW}$

$<1 \mathrm{~kW}$

Fuel pump rate

$80 \mathrm{l} / \mathrm{min}$

Oil pump rate

$40 \mathrm{l} / \mathrm{min}$

DC generator (for starting other engines)

$18 \mathrm{~kW}$

a. AB-90 prop produces high vibration in ground application, shortening service life by 1.7 times

b. INEEL observed max EGT of $410 \mathrm{C}$ at Maximum power (ambient $0 \mathrm{C}$ ). 